\title{
Miten kansasta tulee vernakulaari?
}

\author{
Kansanrunoudentutkimuksen, kirjallisuushistorian ja kansankirjoittajien \\ tutkimuksen kansakuva 1820-luvulta 2010-luvulle
}

\author{
Niina Hämäläinen, Kati Mikkola, Ilona Pikkanen ja Eija Stark
}

$\mathrm{V}$ ernakulaarin käsitettä on viime vuosina alettu käyttää enenevässä määrin ilmiöistä, joita aiemmin on kuvattu kansankielisiksi, kansanomaisiksi tai kansankulttuuriksi. Tämä heijastelee syvällisempää muutosta aiemmin kansaksi määriteltyjen tai siihen tiiviisti kytkeytyvien monimuotoisten tutkimuskohteiden, mutta myös tiettyjen tutkimusalojen luonteen ymmärtämisessä. Mahdollisia syitä vernakulaarin käyttöön tutkimuskirjallisuudessa ja tutkijoiden analyyttisenä työkaluna voi etsiä kansaan liittyvistä poliittisista ja ideologisista konnotaatioista. Erityisen merkittäviä kansan ja kansallisen sisältöjen historiallisia määrittäjiä ovat olleet humanistisiin aloihin kuuluneet tieteet ja erityisesti historiaa, kieltä ja kulttuuria tutkivat oppialat, joilla pitkälti vakiinnutettiin kansa- ja kansakunta-diskurssit.

Tarkastelemme artikkelissamme kansan ja vernakulaarin käsitteiden käyttöä pitkällä aikavälillä seuraavien kysymysten avulla: 1) Millä tavoilla kansan olemusta ja sen toimijuutta on määritelty ja (usein) rajoitettu oppineiston käymissä kansanperinteeseen ja kirjallisuushistoriaan kytkeytyvissä keskusteluissa'? Miten käsitettä kansa ja sen johdannaisia on käytetty ennen niin sanottua vernakulaarin käännettä? 2) Miten kansanomaisen rinnalle tai tilalle ilmestyy tietyissä keskusteluissa vernakulaari (ks. myös teemanumeron johdantoartikkeli)? 3) Millä tavoin vernakulaari suuntaa tutkijan katsetta ja tutkimusta toisin? Entä mitä uusia ilmiöitä ja prosesseja se mahdollisesti auttaa näkemään?

Folkloristi Diane Goldstein (2015) liittää vernakulaarin käänteen viime vuosikymmeninä voimistuneeseen suuntaukseen, jossa tutkimuksellinen mielenkiinto on kohdistunut kulttuurin kerronnallisuuteen sekä henkilökohtaisen ja paikallisen tiedon merkityksiin. Vernakulaarin käsitettä käytettiin kulttuurintutkimuksessa jo 1960-luvulla (ks. esim. Lantis 1960), mutta käsite on yleistynyt laajempaan käyttöön vasta 2010-luvulla, eritoten yhdysvaltalaisessa tutkimuksessa (mm. Howard 2005; Bauman 2008; Goldstein 2015).

Aineistolähtöisen artikkelimme luvuissa kansa-käsitettä ja sen johdannaisia lähestytään neljästä suunnasta: 1) 1800-luvun alun fennomaanien toimittamien kansanrunojulkaisujen, 2) ensimmäisten suomenkielisten kirjallisuushistorioiden, 3) suomalaisen 
kansanrunoudentutkimuksen ja 4) 2000-luvun kansankirjoittajiin kohdistuvan tutkimussuuntauksen kautta. Valitsemamme näkökulmat havainnollistavat hyvin sitä, miten käsitystä kansasta ja kansanomaisesta on tuotettu eri aikoina. Emme pyri esittämään kansa-kuvauksen muutoksia tyhjentävästi, vaan osoitamme joitakin keskeisiä linjoja, jotka havainnollistavat tutkimuksen painopisteissä tapahtuneita muutoksia. Artikkelimme kaikissa luvuissa johtoajatuksena toimii kysymys siitä, mitä kansa-diskurssilla on tehty. Laajemmin tarkasteltuna kyse on siitä, mitä käsitehistoria tietyissä kansallisissa tieteissä on ja miten se synnyttää, vahvistaa ja ylläpitää käsityksiä, joiden kautta hahmottuu yhteiskunnallisia, poliittisia ja sosiaalisia rajoja. Artikkelimme näin ollen pohtii tieteellisten käsitteiden pitkäikäisyyttä ja hahmottelee, miksi "kansasta" on suomalaistutkimuksissa haluttu pitää kiinni, vaikka käsitteen ongelmallisuus on tiedostettu ja käsitelty tutkimuksissa toistuvasti.

Artikkelin aluksi selvitämme kansan käsiteanalyyttistä taustaa. Sen jälkeen siirrymme tarkastelemaan varhaisten kerääjien ja julkaisijoiden kansa-määritelmiä sekä kirjallisuushistorian roolia kansallisen kulttuurin rakentamisessa. Tämän jälkeen pohdimme sitä, miten käsitys kansanrunojen tuottajasta on muuttunut kansanrunoudentutkimuksessa. Lopuksi tarkastelemme, millaisena kansaksi, rahvaaksi tai itseoppineeksi määrittyvä väestönosa näyttäytyy 2000-luvun alussa käynnistyneessä monitieteisessä 1800-luvun kansankirjoittajien tutkimuksessa.

\section{Kansan käsiteanalyyttistä taustaa}

1800-luvun kontekstissa kansa-käsitteen taustalla vaikuttivat yhtäältä romanttiset näkemykset kansasta kansallisen sielun ja aitouden ilmentymänä, toisaalta valistuksen ajalta periytyvä näkemys kansasta tietämättömänä, sokeana ja valistusta tarvitsevana yhteiskunnallisena ryhmänä. Suomen kielessä kansakunnan ja kansallisen käsitteet päädyttiin johtamaan nimenomaan sanasta kansa (/kanssa) - toisin kuin useimmissa muissa Euroopan maissa, joissa vastaavilla käsitteillä viitattiin ennen kaikkea urbaaneihin traditioihin ("borgare" ja "bürger") (Stenius 2003, 320-321). Poliittisessa käytössä kansa on yhdistetty yhtäältä etnisesti homogeeniseen nationalismiin, toisaalta Ranskan vallankumouksen perintöön, jossa on korostunut kansan oikeutettu vastarinta. Näin kansa-käsitettä on käytetty sekä kansakunnan rakentamisessa että vallitsevien rakenteiden haastamisessa. (Liikanen 2003, 258.)

Viime vuosikymmenten aikana erityisesti folkloristiikan alan tutkimuksissa kansa-käsitteen käyttöä on pidetty ongelmallisena muun muassa sen voimakkaan ideologisuuden vuoksi, ja tilalle on ehdotettu vernakulaarin käsitettä (Bauman 2008; ks. Goldstein 2015). Tästä huolimatta kansa-käsite on ollut käytössä yhä 2000-luvulla esimerkiksi 1800-luvun kansankirjoittajien tutkimuksessa. Toisaalta kirjallisuudentutkimuksessa kansan ja kansallisen käsitteitä ei ole yleisesti pidetty hankalina, vaikka niitä onkin tarkasteltu kriittisesti suhteessa kansallisen kirjallisuushistorian muodostamiseen. ${ }^{2}$ Erityisesti kansallisen kulttuurin suhde kirjallisuuden muodostumiseen ja sen määrittelemiseen on ollut ajattelun polttopisteessä. Kirjallisuudentutkimuksen kriittinen katse on kansa-käsitteen sijaan kohdistunut kansallisen ja rajoja ylittävän kirjallisuuden väliseen suhteeseen sekä kansallisen kirjallisuuden pohjimmaiseen ylirajaisuuteen (Grönstrand et al. 2016; Lönngren et al. 2015). 
Richard Bauman (2008) korostaa vernakulaarin filologian olevan amerikkalaisessa folkloristiikassa tekstikeskeistä. Vernakulaari kytkeytyy Baumanin kirjoituksessa ennen kaikkea kulttuurin tekstualisointiin, toisin sanoen siihen, miten suullisesta perinteestä muokattiin keruun, julkaisun ja muun dokumentoinnin avulla kirjallista, ja miten kansa tässä prosessissa kuvattiin tietynlaiseksi. Eri puolilla Eurooppaa aloitettiin 1700-luvun lopulla kansanrunojen julkaisuprojekteja, joita yhdisti kiinnostus menneisyyden maailmoihin (Apo 2006, 216). J. G. Herderin Ranskan vallankumousta edeltäneet ajatukset kansasta (Volk) kansanrunojen tekijänä ja laulajana levisivät myös Suomeen. Kun tietoisuus kansanrunoista ja niiden sisältämästä historiasta alkoi vahvistua Suomen suuriruhtinaskunnan suomenmielisen sivistyneistön keskuudessa (Sihvo 2003, 56), myös käsite kansa alkoi muotoutua ja saada sosiaalisen luokan (rahvas) sijaan muita ominaispiirteitä. Kansa viittasi vielä 1800-luvun alkupuolen Suomessa vaihtelevasti kieleen, kansakuntaan tai kansallisuuteen (Arwidsson 1821; Linsén 1819), vaikka kansa saatettiin nimetä myös kollektiivisesti runojen tekijäksi (Porthan [17661778] 1983 [1766-1778], 39;Topelius 1822). Kansan katsottiin muodostuvan sekä kielellisesti että historiallisesti (sisällöllisesti), ja kansanrunojen keruun ja julkaisemisen myötä kansaksi hahmottui vähitellen se ihmisjoukko, joka puhui suomea ja lauloi vanhoja myyttis-eeppisiä runoja. Kuitenkin vasta Lönnrotin Kalevalan (1835) ilmestymisen jälkeen kansan käsite sai kansallisen ja ideologisen merkityksen, joka sillä on ollut tähän päivään asti. ${ }^{3}$

Kansanrunokokoelmien lisäksi oikeaoppista ja -sisältöistä kieltä ja kirjallisuutta ryhdyttiin 1800-luvun ensimmäisinä vuosikymmeninä määrittelemään kirjallisuushistorioiden avulla. Kirjallisuudentutkija Alexander Beecroft (2015) on kehittänyt mallin kuudesta kirjallisuusjärjestelmästä tai -ekologiasta, jotka selittävät kirjallisuuden kentän pitkän aikavälin dynamiikkaa ja muutoksia. Beecroftin mukaan uusi kirjallisuus syntyy aina kitkaisessa suhteessa olemassa olevaan kirjallisuuteen. Kirjallisen muutoksen ymmärtämiseksi pelkkä kirjallisuuden sisällön tutkimus ei siis riitä, vaan on myös syytä hahmottaa niitä valintoja, joita kirjoittaja kussakin tilanteessa tekee suhteessa tarjolla oleviin ilmaisullisiin vaihtoehtoihin ja sitä kautta tavoiteltuun yleisöön.

Tämän artikkelin kannalta kiinnostava on Beecroftin rakentama ero vernakulaarin, jonka voisi kirjallisuushistoriallisessa yhteydessä kääntää paikalliskieliseksi, ja kansallisen kirjallisuuden välillä. Vernakulaareja kirjoitettuja kirjallisuuksia on syntynyt eri puolilla maailmaa, eli ilmiö on mitä suurimmassa määrin globaali. Vernakulaarit kirjallisuudet saivat alkunsa symbioottisessa, usein täydentävässä suhteessa kulloiseenkin kosmopoliittisella kielellä laadittuun kirjallisuuteen (läntisessä Euroopassa latinankielinen kirjallisuus), mutta ne laadittiin toisenlaista, alkuvaiheessa pääasiassa suppeampaa, paikallista yleisöä silmällä pitäen. Täysin kehittyneellä vernakulaarilla kirjallisuudella on taustallaan kehittynyt sanasto ja standardoitu kielioppi, ja se sisältää myös puhtaan esteettisiä tarkoituksia palvelevia lajeja. Beecroftin mallissa vernakulaaria kirjallisuutta ei kuitenkaan koskaan motivoi nationalistinen agenda; vernakulaarikielen valinta tehdään aina suhteessa hegemonisessa asemassa olevaan kieleen ja sen kautta avautuviin kirjallisuudenlajeihin. Vähitellen vernakulaarit kirjallisuudet kerryttivät kuitenkin riittävästi historiallisia kerroksia, välimatka paikallisen ja kosmopoliittisen kielen välillä kasvoi ja - erityisesti Euroopassa - kosmopoliittinen kirjallisuus menetti poliittis-yhteiskunnallisten muutoksien myötä merkitystään. Kirjallisuutta ryhdyttiin

3 Tarkka et al. puhuvat Herderiin viitaten suomalaisuuden homogenismista, joka voimistui Lönnrotin toimitustyön seurauksena. Kansa-käsitteen kannalta yhtenäistäminen merkitsi ennen kaikkea sitä, että kaikenlaiset yksilölliset piirteet häivytettiin niin runoteksteistä kuin niitä laulaneista henkilöistä. (Tarkka et al. 2019, 86.) 
laatimaan kansallisesta lähtökohdasta eli ajatellen, että kullakin maantieteellisesti rajatulla poliittisella yhteisöllä tuli olla oma kielensä ja kirjallisuutensa - sekä kirjallisuushistoriansa.

Napoleonin sotien jälkeisessä Euroopan jälleenrakentamisessa nämä kansallistuvien kirjallisuuksien historiat rakensivat jatkumoja aiempina vuosisatoina samoilla maantieteellisillä alueilla laadittuihin vernakulaareihin teksteihin. Toisin sanoen omassa historiallisessa kontekstissaan aivan muita tarkoituksia täyttäneet kirjoitukset omittiin nyt kansakunnan luomisessa välttämättömän ajallisen jatkuvuuden ja kronologisen syvyyden rakentamiseen (ks. myös Polén [1858] 1988, 44-45). Suomen suuriruhtinaskunnassa tämän prosessin alkuvaiheisiin osallistuivat keskeisesti varhaiset kansarunojen julkaisijat, kuten Carl Axel Gottlund, Elias Lönnrot ja Zacharias Topelius vanhempi. Seuraavaksi siirrymme tarkastelemaan, mitä kansa heille tarkoitti ja millaisia merkityksiä kansaan liitettiin ennen Kalevalaa.

\section{Runous ja kansa}

A. I. Arwidsson (1821) kiteytti ajan hengen esittäessään, että kansan menneisyys ja historia olivat saavutettavissa kansan (rahvaan) laulamien runojen kautta:

Se [kansan runous] kuvaa meille kirkkaissa ja loistavissa muodoissa kansan elämänvaiheet, ja joskaan ei meillä enää olekaan mitään suurempia runoluomia, jotka vesikaaren vaihtelevilla väreillä esittävät meille esi-isäin runsasvaiheista elämää, niin kansan menneisyys ja sen historia kuvastuvat kumminkin tarkasti kaikkiin kotimaisiin runotuotteihin. (Arwidsson [1821] 1931, 115.)

Arwidsson jatkoi, että rahvas ei ymmärtänyt runoutensa arvoa: "maalaisilla on melko varastot vanhoja laulujamme, jotka heillä ovat käyttämättöminä" (Arwidsson [1821] 1931, 121), ja sen vuoksi runot olisi saatettava kerääjien ja julkaisijoiden käytettäviksi. Koska oltiin tavoittelemassa ihanteellista menneisyyttä, runouden kantama estetiikka ja tieto määrittivät kansanrunojen julkaisutoimintaa. Ajatteluun yhdistyi myös moraalinen arvo: hyvä runous sisälsi oikeanlaista, menneisyyteen pohjautuvaa tietoa. Erityisesti loitsujen katsottiin valaisevan menneisyyden yhteisöjä ja tapoja (Porthan [1766-1778] 1983, 88-92; Anttila [1931, 1935] 1985, 87). Samalla runous rinnastettiin runoa laulaviin ihmisiin ja näiden "hyviin tapoihin ja siveellisyyteen" (Kurkela 1989, 213). ${ }^{4}$

Sekä varhaisessa kansanrunojen keruu- ja julkaisutyössä että hieman myöhemmässä tutkimuksessa runolajien välinen hierarkia oli selvä. Arvojärjestys esitettiin jo Henrik Gabriel Porthanin tutkimuksessa Suomalaisesta runoudesta (1766-1778). Siinä todettiin, että nykyiset, loppusoinnulliset laulut ovat arvottomia, ja niitä arvostavat vain ne, jotka eivät kykene ymmärtämään loppusoinnuttomia runoja (Porthan [1766-1778] 1983, 46). 1800-luvulla rahvaan parissa yhä suositummaksi muodostunut niin kutsuttu uusi laulu ${ }^{5}$, eli loppusoinnullinen riimillinen laulu, sekä paikallisia asioita ja ihmisiä kommentoiva rahvaanruno eivät myöskään kelvanneet Kalevalan tai Kantelettaren aineistoksi. ${ }^{6}$

\footnotetext{
4 Runouden kantama tieto oli esillä jo Porthanin kirjoituksissa (Karkama 2001, 42-44), ja yhteyttä vahvisti mm. Lönnrotin ajatus kansanrunoista historiallisina. Ks. Saarelainen 2019.

5 Viittaamme tässä artikkelissa "uudella laululla" sekä riimillisiin lauluihin että kalevalamitalla esitettyihin, ajankohtaisia ja paikallisia asioita käsitteleviin rahvaanrunoihin. Kansanrunojulkaisijat puhuivat nykyisistä lauluista (riimilliset laulut) ja nykyisistä runoista (rahvaanrunot).

6

Kantelettaren esipuheeseen riimilliset laulut sopivat vain lajin tyypillisiksi näytteiksi.
} 
Uuden laulun asemointi vähäisemmäksi runolajiksi vahvistui 1800-luvun keruu- ja julkaisutoiminnassa (ks. Asplund 2006; Kurkela 1989), mutta lajin alhaisempi asema oli näkyvissä jo ensimmäisissä suomenkielisissä kansanrunokokoelmissa. Näissä vanha laulu muodosti pääosan (2/3) aineistosta ${ }^{7}$, vaikka kokoelmat sisälsivät myös riimillisiä lauluja ja rahvaanrunoja. Runokokoelmien vastaanotto heijasti niiden toimittajien sisällöllisiä valintoja. Laajalti arvostusta nauttineet ja kokoelmilleen myönteisen vastaanoton saaneet Lönnrot ja Topelius (Sihvo 2003, 69; Anttila [1931, 1935] 1985, 88-89) ottivat mukaan runsaasti arvostettuja loitsuja (molemmilla lähes puolet runoista), kun taas Gottlundin Pienissä Runoissa loitsuja oli vain muutama. Gottlundin Väinämöiset pohjautui pelkästään ajankohtaisia ja paikallisia asioita kommentoiviin rahvaanrunoihin. Sivistyneistön piirissä Gottlundin kokoelmat eivät saaneet kovinkaan myönteistä vastaanottoa: kieli oli murteellista ja Väinämöiset-kokoelman sisältö liian seksuaalisväritteistä ja ajankohtaista sivistyneistölukijoiden esteettiseen makuun (Apo 2009, 4-5).

Uuden laulun alempi asema näkyi myös muissa kirjoituksissa. Lönnrotin arvio Topeliuksen runokokoelman neljännestä osasta ("Recension"/Helsingfors Tidningar 1829) keskittyi runojen osalta loitsuaineistoon. Silloin kun Lönnrot mainitsee joitakin kokoelman nykyisistä lauluista tai faabeleista, hän korostaa, etteivät ne kuuluneet rahvaan tavallisesti laulamiin runoihin, kansan runoestetiikkaan: "höra icke till almogens poetiska runoprodukter". Toisaalta julkaisijat myös ymmärsivät nykyisten laulujen luonteen, mutta sen estetiikka ja moderni kuvasto eivät sopineet myyttiseen menneisyyteen kohdentuvaan julkaisuprojektiin. ${ }^{8}$

Julkaisutoimintaa perusteltiin paitsi vanhojen runojen rappeutumisella ja lopullisella häviämisellä, myös vetoamalla runojen "aitouteen" eli suulliseen välittymiseen, kollektiivisuuteen sekä kielelliseen ja sisällölliseen puhtauteen. Gottlund vetosi suomalaisuuteen ja suomen kieleen, jonka "tyhmät veisut" eli kirjallisperäiset runot (fantasi, diktkonst) tuhosivat:

Sillä meijän Runomus elää niissä pohjoisimmissa moakunnissa kansan suussa, ei niissä tyhmissä veisuissa, joita vuosittain painetaan ja levitetään ympäri moatamme, ja jotka murtaavat ja murhaavat sekä kielemme että juohutuksemme (Fantasi, Diktkonst). Ne eivät onk Suomalaisia, muuten kuin nimekseen, sillä heissä osoittaiksen yksi muulainen Runomus puettu Suomalaisilla sanoilla, mutt' ei käytetty Suomalaisella kielellä. (Gottlund 1828, Väinämöiset, v.)

Lönnrotin näkemykset, jotka sittemmin syvenivät Kantelettaren esipuheessa (1840), olivat iduillaan jo varhaisessa toimitustyössä. Kantelettaressa Lönnrot määritteli kansanrunojen eri lajeja ja lyriikan olemusta sekä käsitteellisti lyriikan kieltä ja tunteita. Esipuhe vahvisti runolajien hierarkkista eroa usealla eri tavalla. Lönnrot eritteli runolajit, joita olivat lauluruno (lyriikka), loihturuno, virsiruno (balladit, kertovaiset ja historialliset runot), kertomaruno ja osotelmaruno (häälaulut). Tähän lajijaotteluun eivät kuuluneet uudemmat laulut. Edelleen Lönnrot selvitti, että runot olivat yhteisiä koko kansalle. Lönnrotin mukaan "[s]amassa kun niitä sanottaisi jonkun erityisen tekemiksi, kadottaisivat kansanrunollisen arvonsa" (VT 5, 320). Nykyiset laulut ja rahvaanrunot eivät voineet edustaa koko kansan runoperintöä, sillä niiden esittäjä ja sepittäjä oli useimmiten tiedossa oleva, nimetty henkilö.

$7 \quad$ Carl Axel Gottlundin Pieniä Runoja Suomen Poijille Ratoxi $(1818,1821)$ ja Väinämöiset, eli meidän nykyisten Runojoin virren-teoista (1828), Sakari Topelius vanhemman Suomen kansan vanhoja runoja ynnä myös nykysempiä lauluja (18221831) sekä Elias Lönnrotin Kantele taikka Suomen kansan, sekä wanhoja että nykysempiä runoja ja lauluja (1829-1831). 1830, tammikuu 1840, ks. VT 2). 
Myöhemmin, J. G. Herderin romanttisia ajatuksia myötäillen, Lönnrot nosti esiin lyriikan asemaa erityisenä kielenä. Herderin mukaan lyriikalla, runouden alkuperäisimmällä ja vanhimmalla kielellä, saattoi ilmaista sellaisia asioita, joita proosan kautta ei voinut sanoa (Herder [1795] 2000, 27). Rempseäsisältöinen riimillinen laulu ei kyennyt kantamaan runokielen siveellistä ja suorastaan jumalaista ulottuvuutta samalla tavoin kuin mitallinen kansanlyriikka, jonka huoliin ja yksinäisyyden tuntoihin kiinnittyvä kuvasto oli Kantelettaren ydinlyriikkaa. Näin runot ja niitä laulanut kansa liitettiin alkuperäiseen, arvokkaaseen ja pyhään.

Ero oikean, vanhan runon ja uudemman laulun välillä löytyi myös sosiaalisesta hierarkiasta. Kouluttamaton, nykyisestä maailmasta ja "herrasväestä" etäällä elävä kansanosa säilytti vanhan runoperinteen parhaiten. Tämän oli selkeästi esittänyt jo Topelius vanhempi, joka korosti vanhojen runojen säilyvän vain sellaisissa olosuhteissa, joissa "asuu Suomen kansa alku puhtaudesa ja arvosa" (Topelius 1823, Vanhoja Runoja II) ja joihin uusi aikakausi ja tavat eivät olleet vielä ulottuneet.

Lönnrot teki Kantelettaressa jyrkän eron taiderunon ja kansanrunon (luonnonrunon) välille korostaen taiderunon olevan oppineen runoilijan tekemistä ja työtä, kun taas kansanruno syntyi itsestään, ajatuksen ja mielen ilmauksena. On kiinnostavaa, että erityisesti Lönnrot ja Topelius välttivät tuomasta esille, että vanhoja, mitallisia runoja esittivät ja julkaisivat myös oppineet, kouluja käyneet henkilöt (vrt. Porthan [1766-1778] 1983, 58-69; ks. Kallio et al. 2017). Väinämöiset-kokoelmansa esipuheessa Gottlund puolestaan nosti kirjallisperäiset runot esiin esimerkkinä siitä, miten ne tuhoavat todellisen suomalaisen kielen ja runon. Luku- ja kirjoitustaidottomuus yhdistettiin yksiselitteisesti vanhoihin runoihin, niiden esittämiseen ja perinteen jatkumiseen.

Varhaisessa kansanrunojen julkaisutoiminnassa ilmenevä lajien arvojärjestys ja menneisyyteen palautuva ajatus oikeasta kansanrunosta ovat vaikuttaneet myöhempään kansa-käsitteen muotoutumiseen sekä Kalevalan ilmestymisen innoittamaan keskusteluun kansakunnasta ja kielestä (ks. Tarkka et al. 2019). Myös tutkimus on sivuuttanut kansanrunokokoelmien sisällöllisen moninaisuuden ja korostanut joko niiden loitsuaineistoa tai esimerkiksi Lönnrotin kohdalla Kantele-vihkojen tarjoamaa eeppistä mallia (Kaukonen 1979, 34-37). Sisällyttämällä kokoelmiin rahvaanrunoja ja riimillisiä lauluja ensimmäiset kansanrunojulkaisut heijastelivat myös kansanlaulun modernia aikaa ja nykytietoa. Kuitenkin niin toimittajat kuin kansanrunokokoelmia lukeva sivistyneistökin painottivat julkaisujen menneisyyskuvastoa heijastavaa myyttis-eeppistä sisältöä, jossa kielen puhtaus ja estetiikka olivat kohdallaan. Tässä eetoksessa Gottlundin nykyistä laulukulttuuria edustavaa Väinämöiset-julkaisua paheksuttiin (Apo 2009).

Käsitys "aidosta" runosta (puhtaus, viattomuus, turmeltumattomuus, menneisyys, myös pyhyys) kiinnittyi väistämättä käsitykseen "aidosta" kansasta. Tässä mielessä (tässä aineistossa) runoa ja kansaa ei voida edes erottaa toisistaan, kun pyritään hahmottamaan käsitettä kansa 1800-luvun alkupuolella, ennen Kalevalan ilmestymistä. Ajan tavan mukaisesti runoja laulaneet inmiset edustivat anonyymia ja tunnistamatonta kansanosaa, josta kansanrunokokoelmiin yksilöitiin ja nimettiin vain malliesimerkit. Oikea, aito, puhdas kansa kiteytyi käsitykseen estetiikaltaan ja moraaliltaan oikeasta runoudesta - ajatus, jonka siemen oli kylvetty jo Herderillä (ks. Apo 2006, 263). Esimerkiksi Lönnrot esitteli Kantelettaren esipuheessa erikseen "oikian laulajan", llomantsin Mateli Kuivalattaren, jonka laulajataidot ja repertuaari olivat tehneet Lönnrotiin suuren vaikutuksen. Tämä päti myös runokokoelmiin 
sisällytettyihin runoihin. Kokoelmiin pyrittiin valitsemaan paras ja kaunein runoaines, kuten Lönnrot Kantele-vihossa (osa II) esitti: "Näistä olen minä valinnut präntättäväksi sen, joka mielestäni on paras ja täydellisin, sillä jokaisellen minä en ole saanut tilaa".

\section{Kirjallisuushistoriat ja kansa}

Lönnrotin sanallistama valikoimisen problematiikka liittyy kirjallisuudentutkija Alexander Beecroftin mukaan myös kirjallisuushistorioiden laatimiseen. Kirjallisuushistoriasta muodostuu 1800-luvulla kansallisen kirjallisuusekologian keskeinen laji, ja eräs sen merkittäviä tehtäviä on poissulkeminen: tiedon määrän rajoittaminen siten, että kanonisista teksteistä ja teoksista syntyy hallittavissa oleva joukko (Beecroft 2015, 197-235).

Suomen alueen varhaista kirjallisuutta esittelevät ensimmäiset kirjallisuushistoriat, esimerkiksi A. J. Sjögrenin Ueber die finnische Sprache und Ihre Litteratur (1821), julkaistiin suuriruhtinaskunnan ulkopuolella. Nämä teokset olivat pääasiassa luetteloita alueella aiempina vuosisatoina lähinnä sivistyneistön tuottamista latinaksi, ruotsiksi ja suomeksi julkaistuista teksteistä - esimerkiksi sana- ja lakikirjoista ja sananlaskukokoelmista. Seuraavassa kirjallisuushistoriallisessa aallossa 1840-luvulla ilmestyi lyhyitä kirjallisuushistoriallisia katsauksia ja poleemis-ohjelmallisia kirjoituksia kansalliskirjallisuuden tarpeesta. (Laitinen 1980, 16-17.) ${ }^{9}$

Varsinainen kirjallisuushistoria sai alkunsa kuitenkin vasta 1850-luvun lopulla, kun maisteri Fredrik (Rietrikki) Polén julkaisi 80-sivuisen väitöskirjansa Johdanto Suomen kirjallishistoriaan. Yliopistollinen kirjoitus $(1858)^{10}$. Polénin puolustaessa väitöskirjaansa kirjallisuutta ei kuitenkaan ollut olemassa beecroftilaisen ajatuksen mukaista hallitsematonta määrää, sillä painotoiminta laajeni suuriruhtinaskunnassa merkittävästi vasta seuraavilla vuosikymmenillä (Häggman 2008, 173). Miksi Polénin kirjallisuushistoria sitten julkaistiin juuri tässä vaiheessa?

Vaikuttaa siltä, että Polénin teoksen taustalla oli kaksi tekijää. Ensimmäinen oli vuosisadan puolessavälissä kiihtynyt ideologis-poliittinen keskustelu suomen kielen asemasta niin tieteen, yhteiskunnan kuin kulttuurinkin kielenä ja tähän kytkeytyvä kysymys suomenkielisen korkeakulttuurisen kirjallisuuden mahdollisuudesta. Pääosa Polénin teoksen sivuista kuluukin kirjallisuuden määrittelyyn sekä suomen kieltä ja kielioppia koskeviin pohdintoihin. Tekijä itse uskoi vankasti siihen, että "Suomenki kieli on niin miehistynyt, että ainoasti sen taitamattomat ja sen ylenkatsojat voivat sitä sadatella raaksi 'pohjanperän kieleksi', joka muka kelpaisi vain savupirteihin ja tuhman talonpojan suuhun..." (Polén [1858] 1988, 9). Polén pääsikin julistamaan kateederilta lähinnä ruotsinkieliselle yleisölleen, että ruotsista ja latinasta oli jo aika luopua ja suomen kieli oli kohotettava valtakieleksi (Polén [1858] 1988, 72-73). ${ }^{11}$

\footnotetext{
9 Tässä vaiheessa kansallisen kielen, kulttuurin ja kirjallisuuden asiaa ryhtyivät edistämään Gabriel Rein ("Om National-Literaturens i Finland utveckling", Suomi 1842), J. V. Snellman ("Inhemsk Litteratur", Kallavesi I-3/1846) ja C. W. Törnegren (Litterära Soiréer II, 1849).

10 Vuoden 1988 uusintapainoksen mukaan.

11 Polénin jälkeen samana syksynä suomenkielistä väitöskirjaansa puolusti historioitsija Yrjö Koskinen. Tämän jälkeen yliopiston kielistatuutteja muutettiin siten, että suomi hyväksyttiin virallisesti väitöskirjojen kieleksi. (Klinge 1989, 531; ks. myös Sulkunen 2004, 124-128.)
} 
Toiseksi Kirjallishistorian tietyt muotoilut viittaavat siihen, että sivistyneistö halusi pitää niin kehittyvän kansalliskirjallisuuden kuin kynää enenevissä määrin käyttävän kansankin tiukasti määrittelyvallassaan. Itsekin suullista perinnettä keränneen Polénin kirjallisuusajattelussa kansanrunoudella oli keskeinen sija, sillä se saattoi luoda perustan aidolle kansalliskieliselle kirjallisuudelle (Polén [1858] 1988, 14, 60). Kyse oli kuitenkin ennen kaikkea sivistyneistön ja pääasiassa Lönnrotin - aloitteesta julkaistusta, toimitetusta ja siistitystä kansan äänestä. Eliitin kirjallisuushistorioiksi tiivistyvän ajattelun mukaisesti kirjallisuuden luomiseen ei siis voinut ryhtyä kuka tahansa, millä muodolla ja murteella vain. Kuten sanottu, kontrolli kohdistui myös tiettyihin sivistyneistön edustajiin, esimerkiksi C. A. Gottlundiin, jotka julkaisivat vähempiarvoisina tai epäilyttävinä pidettyjä runolajeja.

Kansan äänenkäytöllä oli tässä ajattelussa tarkasti määritellyt rajansa. "Todellisena vastuksena ja pönkkänä" oikean kansalliskielisen kirjallisuuden aikaansaamiselle olivat oppimattomat kynänkäyttäjät, "työjuhdat" joita oli "ruvennut ilmautumaan suomen kielisenki kirjallisuuden vainiolle, enemmin rahan ja oman voiton himosta kuin totisesta rakkaudesta ja taipumuksesta kirjallisiin toimiin" (Polén [1858] 1988, 13). Jos ja kun tällainen pääasiassa yksilöllistä hyötyä silmällä pitävä, kirjallisia toimia harrastava oppimaton joukkio vielä "heitti kielioppisäännöt tuntemattomaan", oli suomalaisten käsissä joukko erilaisilla paikallisilla puheenparsilla laadittuja teoksia, "onnetoin sekasotku, joka hengellisesti murhaisi koko kansan" (Polén [1858] 1988, 16).

Polénin yliopistollisen kritiikin kohteena saattoivat muun muassa olla sivistyneistön kontrollin ulkopuolella olevat arkkiveisut sekä niiden laatijat ja levittäjät (ks. esim. Hakapää 2013). Näiden jo edellä mainitun Gottlundinkin "tyhmiksi veisuiksi" määrittelemien tekstien epäilyttävästä sisällöstä antoi tuomionsa myös Julius Krohnin postuumisti julkaistu kirjallisuushistoria Suomalaisen kirjallisuuden vaiheet 40 vuotta myöhemminkin (Krohn 1897, 253). Kokonaisuutena Krohnin teos edusti kuitenkin jo aivan toisia kirjallisuushistoriallisia lähtökohtia kuin Polénin pamflettimainen väitöskirja. ${ }^{12}$ Sen lähes 500 sivua kartoittaa yksityiskohtaisesti suomenkielisen kirjallisuuden historiaa Mikael Agricolasta Juhani Ahoon. Erityisesti 1800-lukua edeltävien vuosisatojen osalta teosta on kuvattu "runsastietoisimmaksi ja tarkimmaksi esitykseksi vanhemmasta suomenkielisestä kirjallisuudesta" (Laitinen 1980, 26). Kirjallisuuden kentän laajetessa 1800-luvun puolenvälin jälkeen astuvat kuvaan modernit, esteettiset arviointi- ja poissuljentaperusteet. Kuten Julius Krohn (tai ehkä pikemminkin hänen editorinsa Kaarle Krohn ${ }^{13}$ ) toteaa:

Tästä lähtien ei, niin kuin tähän asti, voi kaikkia ansiokkaita kirjateoksia luetella, vaan on täytymys sekä rajoittaa että valikoida. Mutta samalla on se nautinto, että saa esittää yhä enemmän todellista kirjallisuutta, eikä vaan semmoista, jolla yksistään tutkijan silmissä on jotakin arvoa. (Krohn 1897, 349.)

Käsitys kirjallisuudesta oli kuitenkin edelleen laaja verrattuna 1900-luvun kirjallisuushistorioihin. Mukaan kirjallisuushistorialliseen kaanoniin pääsivät niin kielitieteilijä ja tutkimusmatkailija M. A. Castrénin "suurten tutkimuksien jalot ilmituotteet" (Krohn 1897, 354) kuin Suomettaren avustajien ja kirjeenvaihtajien moninaiset julkaisut. Tällä monimuotoisen kirjallisuuden esittelyllä Suomen kirjallisuuden vaihteet -teoksen 1800-lukua käsittelevä osuus osoitti, kuinka sivistyneistö oli onnistunut muuttumaan: kansallistamalla itsensä se oli

\footnotetext{
12 Välissä oli julkaistu seitsemän kirjallisuushistoriaa niin suomen- kuin ruotsinkielisestäkin kirjallisuudesta (ks. Laitinen 1980, 44).

13 Ks. teoksen esipuhe (Krohn, K. 1897, IX).
} 
luonut alati kasvavan kansalliskirjallisuuden. Krohnien sääty-yhteiskunnan viimeisten vuosikymmenien arvoja heijastavalle kansa-suhteelle oli kuitenkin kuvaavaa, että kansan olisi pohjimmiltaan, sivistyneistön tuottamien lehtien, oppikirjojen ja kirjastojen avulla sivistyessäänkin, pitänyt pysyä muuttumattomana. Kirjallisuushistorioitsija-Krohn suree suomalaisen rahvaan runollisen olemuksen sammumista sen ryhtyessä kaikenlaiseen modernisoituvan yhteiskunnan tarjoamaan "maallis-rahalliseen asioitsemiseen". (Krohn 1897, 266, alaviite 1 ; ks. myös 253.)

Lönnrotin julkaisemaa kansanrunoutta lukuun ottamatta Polénin lyhyen Kirjallishistorian lähtökohtana olivat olleet oppineiden tuottamat tekstit kautta aikojen. Muiden sosiaalisten ryhmien kynänkäyttäjistä mainitaan ainoastaan Tuomas Ragvaldinpoika (1724-1804), mutta hänenkin kohdallaan jätetään tuotannon arkkiveisupainotus mainitsematta (Polén [1858] 1988, 53). ${ }^{14}$ Krohn sen sijaan otti mukaan laajasti 1600- ja 1700 -lukujen "talonpoikaisia runoniekkoja", kuten Konsaheikin, köyhän työmiehen Oulusta, joka "kuoli lämpöiseen uuninkiukaaseen, johon oli viinapäissään mennyt makaamaan" (Krohn 1897, 155). Rahvaanruno, joka oli ollut kansanrunojulkaisijoiden silmissä epäkiinnostavaa, jopa väärää, sopi kirjallisuushistorioihin välittäväksi lajiksi aiemman kansanrunouden ja kansalliskirjallisuuden välille. Krohnin Suomalaisen kirjallisuuden vaiheet -teoksen kattavuutta ja sen pitkää merkitystä kuvastaa se, että Otavan 1930-luvun päätyön, mittavan ja suuritöisen kansalliskirjallisuuden antologian Suomen kansalliskirjallisuus I-XV12. osan "Talonpoikais- ja taiderunoilijoita, sanomalehti- ja aatteenmiehiä 1800-luvun puoliväliltä" 30 tekijästä ainoastaan kolme ei sisälly Krohnin 1890-luvun kirjallisuushistoriaan. ${ }^{15}$ Krohnin Suomalaisen kirjallisuuden vaiheet siis vakiinnutti vuosikymmeniksi kuvan varhaisista kirjoittavista kansanihmisistä.

Suomalaisen kirjallisuuden vaiheiden vihoviimeisillä sivuilla "todellisen kirjallisuuden" kategoriaan sisällytetään myös kansankirjailijat eli "kirjailijat, jotka kuvaavat talonpoikaisen kansan elämää itse siihen kuuluvina" (Krohn 1897, 469). Kansankirjailija-käsitteen synty liittyi nopeaan yhteiskunnalliseen muutokseen, jonka myötä 1870- ja 1880-luvuilla kirjailijoina debytoineista jo yli 40 prosenttia oli talonpoikien tai työväestön jälkeläisiä. ${ }^{16}$ Krohnin kirjallisuushistoria kuitenkin häivytti tätä modernin murrosta kytkemällä uudet kansankirjailijat itsestään selvästi osaksi vuosisataista jatkumoa "vanhain kansanrunoilijain ja uudempain talonpoikaisten runoniekkain kanssa" (Krohn 1897, 469).

Krohnin teos ei silti aivan - kenties tekijänsä kuoleman (1888) johdosta - ehdi hahmottaa tätä laajenevaa ja näkyvää kirjallisuuden kenttää. ${ }^{17}$ Mukaan on otettu ainoastaan Pietari Päivärinta, jonka kaunokirjallisiksi ja sivistyshistoriallisiksi arvioitujen teoksien kautta "[m]e näemme silmiemme edessä Pohjolan kansan pinnaltaan karkeana, vaan sisällisesti jalona" (Krohn 1897,471).Vaikka sivistyneistön piirissä annettiin Päivärinnan teoksien kansanelämän kuvaukselle saman tyyppinen dokumenttiarvo kuin Kalevalalle (Häggman 2001, 73), vahvistivat luonnehdinnat Päivärinnasta ja tämän edustamasta estetiikasta samalla kirjallisuushistorioissa hahmoteltua epähistoriallista kansankirjailija- ja kansankirjallisuus-kategoriaa, joka

\footnotetext{
14 Lisäksi mainitaan kirkkoherra Abraham Achrenius, joka kirjoitti suomenkielisiä virsiä.

15 1930-luvun lisäykset ovat Pietari Kettunen, "vienankarjalainen runoniekka", Jaakko Räikkönen, "inkeriläinen kansanrunoilija, kunnallinen toimihenkilö ja valistusmies", sekä Frans Pietari Kemelli, "runoilija, pappi" (Setälä, Tarkiainen ja Laurila 1933).

16 Kansankirjailija-käsitteestä laajemmin ks. esim. Lång 2008, 70.

17 WSOY ryhtyi 1880-luvulla julkaisemaan kansankirjoittajien teksteistä Syvistä riveistä -valikoimaa (Häggman 2001, 74-75).
} 
siirtyi sellaisenaan 1900-luvun alkupuolen kirjallisuushistorioihin. Kuvaavaa on, että aikakauden keskeinen kirjallisuushistorioitsija Viljo Tarkiainen yhdisti Päivärinnan poetiikan suoraan keskiaikaisen kirkkotaiteen (oletettuihin) kansallisiin vaikkakin kehittymättömiin piirteisiin: tämän teokset näyttivätt "jäykiltä ja kömpelöiltä niin kuin se kuvaamataide, joka esiintyy vanhoissa maalaiskirkoissamme veistokuvina ja seinämaalauksina" (Tarkiainen 1904). ${ }^{18}$

Sisäänrakennettuna 1800-luvun alkupuolen kansalliskirjallisuuden ohjelmajulistuksiin ja vaatimusmäärittelyihin oli jatkuva kysymys siitä, oliko "torpparikansa" kypsä tuottamaan ja kuluttamaan korkealaatuista kirjallisuutta, jota ei tarvitsisi hävetä suhteessa muiden kansakuntien tuotoksiin (Polén [1858] 1988, 34). ${ }^{19}$ Kirjallisuushistoriallisessa ajattelussa kansakuntakokonaisuuden arvonmuodostus tapahtui siis sen yhteisöllisen kehitysvaiheen jatkuvassa vertailussa toisiin yhteisöihin. Kuten J. G. Herder asian muotoili 1800-luvun käänteessä: "[h]uomaamatta joudumme siis tutkimaan, mitä kukin on jokaiseen kaltaiseensa nähden oman kansakuntansa sisä- ja ulkopuolella, mitä hänen kansakuntansa toisiin nähden eteenja taaksepäin..." (Herder 1804, 98; lainaus Laitinen 1980, 10-11).

Jatkuva vertailu synnytti suomalaisille tutkijoille tyypillisen ambivalentin asetelman: Suomi käsitteellistettiin keskeneräisyyteen viittaavin termein. Samalla kehittyi mielikuva ajallisuudesta, jossa Suomi liikkui eteenpäin, kohti maalia, jonka muut Euroopan maat olivat jo saavuttaneet (Jalava 2014, 43). Tällä takapajuisuus-diskurssilla oli kuitenkin myönteinen kääntöpuoli. Vielä 1900-luvun alkuvuosikymmeninä ajateltiin, että suomalaisuuden myöhästynyt lähtö sivistysvaltioiden välisessä kilpailussa saattoi koitua maan ja sen asukkaiden eduksi: sivilisaation lineaarisessa kehittymisessä perässätulijat ottivat edistyneempiä kiinni ottamalla mallia niiden saavutuksista, mutta samalla välttäen näissä tehtyjä virheitä (Kettunen 2001, 232-233; 2006, 288-289; ks. myös Polén [1858] 1988, 8). Tilanne muuttui 1940luvun kirjallisuuspuheessa, kun epävarma poliittinen tilanne vaati elinvoimaisen kansalliskirjallisuuden korostamista (Lassila 1990, 91). Rafael Koskimiehen Elävä kansalliskirjallisuus -teoksen (1944) ensimmäisen osan mukaan "kansa joka jo keskiajalla ja uuden ajan alussa on keskuudessaan tuhlaillen luonut valtavat, rönsyilevät, ikirehevät muinaisrunonsa ei ole osaton eikä kokonaan myöhästynyt kansa..." (Koskimies 1944, 12).

\section{Kansanrunoudentutkimus ja kansa}

Suullinen perinne määriteltiin vielä 1960-luvun alun kirjallisuushistoriassa kirjoittamattomaksi "kirjallisuudeksi" (Kuusi 1963). Elias Lönnrotin tai muiden varhaisten julkaisija-toimittajien työskentelyä runojen keruussa tai järjestelyssä ei vielä voida pitää varsinaisena kansanrunojen tutkimuksena. On siis syytä tarkastella erikseen akateemisen kansanrunoudentutkimuksen käsitystä tutkimuskohteen, kansanrunojen, tuottajasta. Nimensä mukaisesti "suomalainen ja vertaileva kansanrunoudentutkimus" keskittyi kansanrunojen vertailun ja luokittelun analyysiin. Voikin pohtia, kumpi tutkijoille on ollut tärkeämpi, runot vai niiden esittäjät.

18 Viljo Tarkiainen: Kansankirjailijoita katsomassa (1904). Lainaus Niemi 1999, 339. Tarkiainen palaa samaan ajatukseen 1930-luvun kirjallisuushistoriassaan, jossa Päivärinnan tyyliä kuvataan “jäykäksi maalaisrealismiksi ja verraten persoonattomaksi puunveistotyyliksi, jossa välistä näkyy horjahtelua karkeuteen, useimmiten kuitenkin sentimenttaalisuuteen päin" (Tarkiainen 1934, 198).

19 Kansakuntien välinen kilpailu ulottui bibliografioiden laatimiseen saakka. Julius Krohnin mukaan Pippingin kirjaluettelo (1857) oli saavutus "jolle täydellisyyteensä nähden ei ole vertaista maailman kirjallisuusluetteloissa" (Krohn [1897] 1953, 282, alaviite 2). 
Tutkijat pyrkivät kansanrunojen avulla selvittämään menneisyyttä, etenkin esihistoriaa, joka nuorelta kansakunnalta puuttui. Ainoastaan suullinen kulttuuri ja tekstin poeettinen muoto läpäisivät aidon kansanrunouden kriteerit, koska ne edustivat vanhempaa aikaa kuin painettu kirjallisuus. Näin ollen varhaisten tutkijoiden tavoitteena oli valaista kansan muinaista suuruutta ja suullista kansankulttuuria osaavat ihmiset olivat heille välittäjiä - Satu Apon sanoin: "viimeinen lenkki ketjussa, jonka kautta idealisoitujen esi-isien henkinen perintö oli siirtynyt sivistyneistön henkilöiden käsiin, jotka ymmärsivät perinnön arvon syvemmin kuin sen haltija ja luovuttaja" (Apo 1998, 95).

Alkuaikojen runonkeruutyö perustui oletukseen, että lukutaito sekä laajempi ymmärrys maailmasta hävittäisivät vanhan suullisen runoperinteen. Kansanrunoudentutkimuksen professoreina toimineiden Kaarle Krohnin (1898-1928), Väinö Salmisen (1933-1947) ja Martti Haavion (1949-1956) tuotannoissa näkyy ajatus siitä, että suullisesti ilmaistu kulttuurinen viestintä oli puhtainta silloin, kun se oli opittu korvakuulolta ja se säilyi muistinvaraisesti (Stark 2019). Keskeistä olivat runous ja runotekstit. Myöhemmin vakiintunut ajatus kansan monimuotoisuudesta tai -selitteisyydestä ei ollut tutkijoille ensisijaista: olennaista oli saada tallennettua kansanrunoutta ja niissä ilmeneviä ikivanhoja käsityksiä ja uskomuksia. Tutkijoiden mielikuvissa kansaa edustivat ennen kaikkea maa- ja metsätaloustöistä elantonsa saavat sekä pyyntikulttuurista riippuvaiset yksilöt kaikkialta Suomesta. Suomalaisen Kirjallisuuden Seurassa esitettiinkin jo melko varhain idea kaikkien Suomen alueiden kansanrunouden keruutyöstä. Kaarle Krohnin 1880-luvulla esittämästä ideasta käynnistyneessä mallissa tämä toteutui erillisten asiamiesten avulla, joita olivat maakunnissa asuvat maisterit, lehtorit, lääkärit ja papit. Keruumatkoja suunnitteleville Krohn kirjoitti oppaan, jossa hän neuvoi kerääjiä välttämään "talolliseksi pukeutumista" ja keskittymään olemaan hyväntuulinen ja rento, sillä asenne ratkaisi kohdattaessa syviä kansan rivejä (Evijärvi 1963, 31). Myöhemmin 1930-luvulla systemaattista vastaajaverkkoa ryhdyttiin muodostamaan Martti Haavion toimesta Ruotsista saadun mallin mukaan (Peltonen 2004, 211).

Suullisen kulttuuri-ilmaisun tekijästä riitti tiedoksi haastateltavan nimi, ikä ja maininta, mistä hän mahdollisesti oli kuullut sanonnan tai kertomuksen. Kansanrunoudentutkimuksen arvo ja laajempi kansalliseksi mielletty merkitys piili kansanrunojen oletetussa aitoudessa ja alkuperäisyydessä (ks. Bendix 1997, 7). Kansankulttuuri rakentui suulliseen kommunikaatiomuotoon: autenttinen kansanperinne välittyi suullisesti, eivätkä siihen olleet vaikuttaneet painettu kirjallisuus tai lukutaidon suoma kyky omaksua laajalti tietoa ja tarinoita. Ei ole liioiteltua väittää, että kirjoitettu kirjallisuus oli pitkään luokkakysymys: monipuolinen, useita eri kirjallisuudenlajeja kattava lukeminen ja kirjoittaminen oli koulunkäynnin vuoksi mahdollista pääsääntöisesti vain ylä- ja porvarisluokille ja ennen kaikkea kaupungeissa asuville. Suomalaisista puolet oli luku- ja kirjoitustaitoisia vuonna 1910, ja luku kohosi jatkuvasti (Leino-Kaukianen 2007, 434). Koska kansanrunoudentutkimus oli kiinnostunut esimoderniksi oletetusta runolaulusta ja kaavamaisesta kertomusperinteestä, jota osasivat syrjäseutujen omavaraistaloudessa elävät, usein heikosti lukevat ja kirjoittavat inmiset, rajattiin kirjoitettu kirjallisuus automaattisesti tutkimusintressin ulkopuolelle. Keruuteknisesti toteutettuna suullisesti ilmaistu kertomus kuitenkin kirjoitettiin paperille ja lähetettiin arkistoon. Siellä se luokiteltiin kerääjän, paikkakunnan ja lajityypin mukaan. Tämä tekstualisaatioprosessi ei kuitenkaan vielä pitkään aikaan synnyttänyt erityistä käsiteanalyysiä kansanrunouden tutkijoiden kirjoituksissa. 
Samaan aikaan kun tutkijat kohottivat maalaiskansan arvokkaiksi määritellyt piirteet arvostuksen ja ihailun kohteeksi, toteutettiin maaseudulla kansanvalistuksellista työtä. Suomen maaseudulla oli 1900-luvun alussa lähes 1800 kirjastoa, joiden kokoelmiin kuului tavallisesti niin uskonnollisia teoksia, Kalevala kuin Shakespearen Macbeth ja muutamia muita maailmankirjallisuuden klassikoita (Luukkanen 2016, 386-388). Kansan tai tarkemmin ilmaisten kansanomaisen elämän ja kulttuurin hahmottamisen historia on siis kahden vastakkaisiin suuntiin toimivan prosessin samanaikaisuutta: oli sekä kansanrunoudentutkimuksen käsitys katoavasta suullisesta runoudesta ja siinä säilötystä mytologiasta että kansanvalistuksellinen, koulutukseen ja sivilisaatiokehitykseen tähtäävä suuntaus. Nämä eivät olleet toisiaan poissulkevia tai kilpailevia ajatussuuntia, vaan ne limittyivät ja menivät päällekkäin. Esimerkiksi Suomalaisuuden Liitto, jossa Kaarle Krohn aktiivisesti toimi, oli perustamassa kirjastotoimintaa ja lukupiirejä kyliin eri puolelle maata 1900-luvun alussa. Krohn perusteli kansanvalitustoimintaansa sillä, että sivistämällä vähäväkisiä heidän henkinen tasonsa nousee, ja he ymmärtävät olevansa osa yhteistä kansakuntaa (Evijärvi 1963, 86-92).

Tämä ristikkäisveto oli suomalaisen kulttuuri-identiteetin rakentamista, jossa älymystö, folkloristit etunenässä, valikoi alemmilta yhteiskuntaluokilta saatua suullista runoutta ja kansanuskoa. Samalla alemmilta luokilta ryhdyttiin odottamaan porvarillisten kulttuuri-ihanteiden mukaista käytöstä ja arvoja. (Anttonen 2005, 148-149.) Kansankulttuurin porvarillistamisessa koulittiin yksilöstä itseään kontrolloiva, siivo ja valistunut suomalainen (Apo 1998, 99). Tutkijat ryhtyivät kohottamaan kansantyyppien esimerkeiksi nimeltä mainittuja runolaulajia ja kuvaamaan näiden elämää. Syntyi ajatus jaloista, viimeisistä runolaulajista.

Yhdenlaista ääripäätä "tyypillisen" kansanihmisen konstruoinnista edustaa Martti Haavion Viimeiset runonlaulajat (1943), jossa esitellään noin neljäkymmentä runolaulajaa pääosin Karjalasta ja Inkeristä. Haavion tutkimusta tulee lukea ajan poliittista ilmapiiriä vasten: Suomi oli jatkosodassa valloittanut alueita Itä-Karjalasta ja Suur-Suomi häämötti monen, muun muassa juuri Haavion, mielessä. Epäilemättä Haavion vilpitön pyrkimys oli nähdä yksilöt runolaulukulttuurinsa takana, vaikka elämäntarinat esitetään idealisoiden ja jopa kaunistellen. Köyhyys, nälkä, sairaudet ja vammat muuntuvat kansanihmistä jalostaviksi ominaisuuksiksi, kun kysymys on epiikan ja itkuvirren taitamisesta (Haavio 1943, 96). Kuten Satu Apo on huomioinut, kansasta esiin nostettuja yksilöitä ylevöitetään tekstissä vertaamalla heitä eurooppalaisen korkeakulttuuritradition hahmoihin. Larin Paraske on "Mnemosyne", antiikin runouden muusa, ja Arhippa Perttunen "Pohjolan Homeros". (Apo 1998, 97.) Voi tietysti pohtia, edustiko Viimeiset runonlaulajat edes omana aikanaan tieteenalalla yleisesti jaettua näkemystä kansanrunojen kansasta. Mitä suurimmassa määrin se epäilemättä oli Haavion oma, persoonallinen käsitys runolaulajista. Teos kuitenkin säilyi tieteenalan opintovaatimuksissa lukukauteen 1969-1970 saakka. Tämän vuoksi ei ole liioiteltua väittää, että Haavion individualismia korostava tulkinta "aidoista kansanihmisistä" vaikutti oppialalla pidempään kuin on kenties aiemmin ajateltu.

Kansanrunoustieteen alalla tapahtui kuitenkin myös tietoteoreettisesti uudenlaisia avauksia jo 1950-luvun aikana. Keskeinen teoreetikko tässä oli Jouko Hautala, joka useissa kirjoituksissaan konstruoi oppialan kansa-käsitettä. Hautalan uudelleenmuotoilussa kansanrunoudentutkimus tutkimusalana käsittää kansanperinteen kokonaisvaltaisesti. Oppialan ytimeksi hahmotettiin nyt uskoon, tapoihin ja runouteen kuuluvat perinteet sekä perinteen elämää, muuttumista ja leviämistä koskevat havainnot ja kansanomainen ajattelu (Hautala 1954, 10). 


\section{Myös oppialan nimi saa Hautalan kirjoituksissa uuden ilmauksen, kansanperinteen tutkimus,} vaikka yliopistolliseksi oppialan nimeksi se kelpuutettiin Joensuuhun vasta 1985.

Kansaa tiukasti kategorisoivista tulkinnoista siirryttiin jo 1950-luvulla väljempiin ja holistisiin kansa-artikulaatioihin, joita Hautala erittelee laajasti teoksessaan Johdatus kansanrunoustieteen peruskäsitteisiin (1957). Kansanrunoustieteessä suunta olikin vaivihkaa siirtymässä pois kansallisesta ja luokkaperusteisesta kansa-käsitteestä kohti mitä tahansa ryhmää, jolla oli yhteistä folklorea. Hautalalle kansan raja asettui nykyaikaisen sivistyneen kaupunkikulttuurin ja maaseudun ja maaseutumaisen kansankulttuurin välille, jolloin periaatteellisesti nykyhetken kulttuuri-ilmiöt kuuluivat myös kansanrunoudentutkijan kiinnostuksen piiriin. Kansanomaisena nähtiin kaikki yhteisöllinen ja perinteellinen (Hautala 1957, 119), joten periaatteessa kansaa saattoi löytää niin maaseudun syrjäkylistä kuin modernista kaupunkimiljööstä. Hieman myöhemmin virinnyt keskustelu suullisen perinteen lajeista vei kansa-käsitystä entistä avarampaan suuntaan. Perinnelajianalyysissä, joka sittemmin jatkui aktiivisena 1980-luvulle saakka, huomio oli lajien viestinnällisessä arvossa käyttäjilleen, lajien määrittelyssä ja niiden luokitteluperusteissa (esim. Honko 1967; Järvinen ja Knuuttila 1982; Knuuttila 1992).

Kansanrunoudentutkimuksen itseymmärryksessä erityisesti 1960-lukua on ajateltu paradigman muutoksen vuosikymmenenä. Jos katsoo kansanrunoustieteen opinnäytteitä, ei muutos näytä kovin radikaalilta. Valtaosa tutkielmista käsitteli kalevalamittaisten runojen ja vanhan kansanuskon tekstitasoja (Järvinen ja Saarikoski 1987). Huolimatta 1950-luvun uusista näkemyksistä oppialan implisiittinen käsitys autenttisuudesta suuntautui luku- ja kirjoitustaidottomien runolaulajien oletettuun maailmaan (esim. Lukin 2016). Mikä 1960-luvun kansanrunoustieteessä sitten muuttui, jos aikakautta pidetään jonkinlaisena vedenjakajana oppialan keskeisen käsitteen ymmärryksessä? Mihin oppialalla tunnettu fraasi "tekstistä kontekstiin" viittasi? IImeinen syy mielikuvaan murroksesta on aikakauden opiskelijaradikalismi, vasemmistolaisuuden suosio opiskelijoiden keskuudessa ja yhteiskunnallinen liikehdintä, jotka heijastuivat myös siihenastisen kansa-käsitteen kritiikkinä.

Aiemmasta täysin poikkeavia olivat Kansanrunousarkistossa toteutetut keruutyöt, jotka kohdistuivat suomalaisiin ala- ja osakulttuureihin. Kansanrunousarkiston vähemmistöjä ja ammattiryhmiä koskevat muistitietokeruut esimerkiksi romaneista, jätkistä ja tavallisista kyläläisistä Hauholla tai Kauhajoella, samoin kuin Työväen arkiston muistitietotoimikunnan perustaminen, olivat signaaleja siitä, miten kansa-käsitteeseen ryhdyttiin eksplisiittisesti sisällyttämään erilaisia todellisuuksia, joissa yksilöiden kokemukset ja perinnerepertuaari asettuivat laajempaan perinne-ekologian viitekehykseen. Toisin sanoen kunkin ihmiskollektiivin - perheen, suvun, harrastepiirin, kylän tai ammattiyhteisön - perinne on omanlaistaan, ei ainutkertaisten aiheiden ansiosta vaan koska se muotoutuu fyysisen ympäristön sekä yhteisössä vallitsevien sosiaalisten, kulttuuristen ja taloudellisten reunaehtojen mukaisesti (Honko 1979, 59-64). Tietyllä tapaa vernakulaari eli yhteisöjen omaehtoinen kulttuuriilmaisu hahmottui implisiittisesti. Sen muotoja 1970-luvulla olivat esimerkiksi iskelmälaulut, lastenperinne ja vitsit (Launonen ja Mäkinen 1974). Terminä vernakulaari ei ollut vielä suomenkielisen tutkimuksen käytössä, mutta sisällöllisessä mielessä se jo vaikutti tutkijoiden ajatteluun ja siihen, mitä tutkimuskohteeseen alettiin sisällyttää. Termi ei vakiintunut suomenkieliseen käyttöön myöskään 2000-luvun alussa virinneessä suomalaisia kansankirjoittajia tutkivassa suuntauksessa. Tämä kirjallistumisen prosesseja tarkasteleva tutkimus 
kuitenkin avasi uudenlaisia käsitteellisiä polkuja kansanomaisen omaehtoisen toiminnan tutkimiseen.

\section{Kynällä kyntävä kansa}

2000-luvulla "kansa" nousi humanistisessa tutkimuksessa esille aiempaan tutkimustraditioon nähden uudenlaisessa kontekstissa, kun monitieteisen tutkimuksellisen kiinnostuksen kohteeksi nousivat arkistojen kokoelmista paikallistetut, aiemmissa tutkimuksissa pääosin täysin vaille huomiota jääneet "tavallisten ihmisten" pääasiassa julkaisemattomat kirjoitukset. ${ }^{20}$ Siinä missä suomalaisen rahvaan kollektiivinen kansanperinne oli tarkoin arkistoitu, analysoitu ja luetteloitu, olivat arkistoon eri reittejä päätyneet, yksittäisten eliittiin kuulumattomien inmisten kirjoitukset jääneet vaille jäsentynyttä tutkimuksellista kontekstia ja mielenkiintoa. Karkeasti ottaen kirjoitukset olivat olleet kirjallisuudentutkijoille "huonoa kirjallisuutta" (jos sitäkään), historiantutkijoille "epäluotettavia lähteitä" ja folkloristeille "epäaitoa perinnettä" - liian omakohtaista ja usein myös kirjallisvaikutteista.

Enimmäkseen 1800-luvulta ja 1900-luvun alusta peräisin olevat käsikirjoitusaineistot herättivät tutkijoiden uteliaisuutta niin kielensä, aiheidensa kuin tekijöidensäkin osalta. Tekstien kirjoittajiksi varmistui usein ruumiillisella työllä itsensä elättäneitä inmisiä, jotka olivat käyneet kouluja vain vähän tai eivät lainkaan. Kirjoittajia alettiin kutsua kansankirjoittajiksi ja itseoppineiksi kirjoittajiksi, ja käsikirjoituksia kansanihmisten kirjoituksiksi (ks. esim. Kauranen 2013; Laitinen ja Mikkola 2013). 2000-luvulla virinnyt itseoppineiden kansankirjoittajien ja yleisemmin 1800-luvun kirjallistumisen tutkimus jatkoi siinä mielessä aiempaa kansan takapajuisuuteen nojaavaa diskurssia, että kansan ja eliitin raja määrittyi edelleen ennen kaikkea ruumiillisen ja henkisen työn sekä kouluja käymättömyyden ja muodollisen koulutuksen kriteerein. Itseoppineisuus ja muodollisen koulutuksen puuttuminen tai vähäisyys tekivät esimerkiksi monista kansanperinteen ja kansanlaulujen kerääjistä tutkimuksen silmissä kansankerääjiä ja kansannuotintajia (ks. Kauranen ja Myllynen 2006; Mikkola 2013; Laitinen, H. 2013). Ajatus kansanomaisesta muutti kuitenkin muotoaan: siinä missä kansa oli aiemmin ollut leimallisesti anonyymi ja kollektiivinen (harvoja harvoja esimerkillisiksi kohotettuja tapauksia lukuun ottamatta), itseoppineiden kansanihmisten tutkimuksessa kansa sai kasvot itseoppineilta kirjoittajilta, joilla oli nimi, elämänhistoria ja oma ääni, jolla he tulkitsivat itse omaa kulttuuriaan - ja kommentoivat osin myös säätyläisten kulttuuria.

1960-luvulla virinneen uuden sosiaalihistorian ja erityisesti mikrohistoriallisen tutkimuksen piirissä oli jo aikaisemminkin kiinnitetty huomiota poikkeuksellisiin kansanihmisiin ja heidän jättämiinsä kirjallisiin jälkiin. 1970-luvulta yleistyneissä "literacy-tutkimuksissa" oli puolestaan pyritty selvittämään makrotasolla luku- ja kirjoitustaidon yleistymistä eri maissa. (Kauranen 2013, 22, 24.) 2000-luvun kansankirjoittajien tutkimuksen aallossa pyrkimyksenä oli hahmottaa sekä kirjoitustaidon yleistymiseen liittyvien kulttuuristen ja yhteiskunnallisten ilmiöiden kokonaisuutta että kansankirjoittajien omaa kokemusmaailmaa ja tulkintoja: Miten ja missä tahdissa kirjoitustaito eri puolilla Suomea yleistyi? Mikä inmisiä motivoi kirjoitustaidon omaehtoiseen hankkimiseen? Mitä ja millaisella kielellä kansanihmiset kirjoittivat? Mitä kirjoitustaito merkitsi ja mahdollisti kirjoitustaitoisille kansanihmisille ja mikä tutkijoiden yhteistyöhön, jota organisoi Kirjallisuusarkiston silloinen johtaja Anna Makkonen (myöh. Kuismin). Yhteistyö alkoi vapaamuotoisina kokoontumisina, joiden pohjalta syntyi useita tutkimushankkeita ja tutkimusverkosto Kansanihmiset ja kirjallistuminen 1800-luvun Suomessa. 
vaikutus sillä oli yhteiskunnalle laajemmin? Nopeasti paljastui, että suomalaisen kulttuurin kirjallistumisesta tiedettiin yllättävän vähän.

Sosiaalihistorioitsija Kaisa Kaurasen (2005) yhdessä Mari Myllysen (2006) kanssa tekemät seikkaperäiset selvitykset SKS:n kirjallisuusarkiston ja kansanrunousarkiston kokoelmista ${ }^{21}$ auttoivat tutkijoita muodostamaan kuvaa siitä, mitä ja millaisia kansankirjoittajien aineistoja arkistoissa ylipäätään oli. Monet tutkijat etsivät ja löysivät kirjoitustaitoisten kansanihmisten käsikirjoituksia myös muiden arkistojen kokoelmista. Lisäksi tutkijoiden yhteistyönä pyrittiin saamaan arkistojen kokoelmiin lisää tähän asti yksityisomistuksessa olleita kansankirjoittajien käsikirjoituksia. Arkistokartoitukset osoittivat, että kouluja käymättömät suomalaiset olivat kirjoittaneet paljon enemmän kuin oli ajateltu ja että heidän tekstejään oli myös säilynyt enemmän kuin oli luultu (ks. Kuismin ja Salmi-Niklander 2008, 1). Samalla kirkastui myös se, että kyse ei ollut mistään marginaalin vaan kirjoittavan enemmistön tutkimuksesta, kuten Lea Laitinen ja Kati Mikkola teoksen Kynällä kyntäjät (2013) johdannossa esittivät:

\begin{abstract}
Suomessa kirjoittavat kansanihmiset olivat paikallisyhteisöissään poikkeuksia, mutta kansallisella tasolla he muodostivat itse asiassa kirjoittajien enemmistön. Esimerkiksi vuonna 1880 maan kahdesta miljoonasta asukkaasta osasi karkeasti arvioiden kirjoittaa 13 prosenttia eli noin 250000 ihmistä. Tuohon joukkoon kuuluivat lähes kaikki säätyläiset, joita oli siihen aikaan korkeintaan 30000 henkeä. Monet heistä osasivat kirjoittaa vain ruotsiksi. Ei säätyläisiin eli rahvaaseen kuuluvia oli kirjoitustaitoisesta väestöstä siis ainakin 220000 henkeä - valtava enemmistö. (Laitinen ja Mikkola 2013, 9.)
\end{abstract}

Englanninkielisissä artikkeleissa alan tutkijat viittaavat tutkimuskohteenaan oleviin henkilöihin muun muassa käsitteillä self-taught writers ja self-educated writers, ja eliitille ja säätyläisille vastakkaiseen ryhmään, johon heidän katsotaan kuuluvan, termeillä non-privileged people, ordinary people ja common people - joskin samaan aikaan tiedostaen ja korostaen, että kirjoitustaitoiset kansanihmiset olivat usein hyvin kaukana niin sanotusti tavallisesta. Tutkimuskohteena oleviin teksteihin viitataan muun muassa käsitteillä ordinary writings, vernacular writings ja kirjallisiin käytäntöihin yleisemmin käsitteillä vernacular literacy practices ja vernacular literacies (ks. esim. Edlund 2014; 2016; Lyons 2007 sekä näiden kokoelmien artikkelit). Vernakulaari merkitsee näissä yhteyksissä usein kansanomaista, ei niinkään tai ainakaan pelkästään kansankielistä.

Suhteessa vernakulaari-käsitteen merkityskenttään on huomattava, että 2000-luvulla tehdyissä 1800-luvun kansankirjoittajien tutkimuksissa vernakulaari ei viittaa useinkaan kansallista edeltävään tai siitä kokonaan irralliseen kulttuuriin (vrt. Beecroft 2015), vaan on suhteessa kansakunnan rakentamisen prosesseihin, joskin eliitin kulttuurista poikkeavana, arjen käytäntöjä ja omaehtoisuutta korostavana ja paikallisia erityispiirteitä sisältävänä kulttuurin muotona. Suomen kontekstissa tätä painotusta selittää aineistojen ajoitus ja luonne: suurin osa aineistosta on 1800-luvulta, autonomian ajalta, jolloin keskustelu suomalaisuudesta oli monin tavoin läsnä yhteiskunnassa ja lisäksi varsin moni eliittiin kuulumattomista kirjoitustaitoisista ihmisistä edusti nimenomaan joukkoa, jota uusi kansallinen ulottuvuus kiinnosti ja innoitti. ${ }^{22}$ Mitä tulee ensikäden lähteisiin, kansakunta-ajattelua ja yhteiskunnan modernisaatioon liitettyjä muutoksia vastustavan ja halveksivan rahvaan ajattelu ja tulkinnat jäävät

21 Arkistot muodostavat nykyään yhdessä Suomalaisen Kirjallisuuden Seuran arkiston, jonka kokoelmat jakautuvat perinteen ja nykykulttuurin sekä kirjallisuuden ja kulttuurihistorian kokoelmiin.

22 Suomessa kansankirjoittajien tutkimus on painottunut niin kutsutulle pitkälle 1800-luvulle eli Ranskan vallankumouksesta ensimmäisen maailmansodan päättymiseen ulottuvalle ajanjaksolle. Tämän aikakauden painottuminen on vaikuttanut osaltaan siihen, että tutkimus on kytkeytynyt monin tavoin 1800-luvun suuriin yhteiskunnallisiin 
itseoppineiden kirjoittajienkin tutkimuksessa pääosin tavoittamatta. Eliittiin kuulumattomat ihmiset, jotka pitivät kirjoitustaitoa turhana ja rahvaalle sopimattomana, harvoin itse kirjoittivat ajatuksistaan (ks. modernisaatioon liitettyjen uutuuksien vastustajien tutkimuksesta esim. Mikkola 2009).

Suomenkielisissä kansankirjoittajia koskevissa artikkeleissa termiä vernakulaari ei ole juurikaan käytetty. Sen sijaan käytössä ovat olleet pääosin samat käsitteet, joilla suomalaisessa tutkimuksessa on operoitu vuosikymmeniä, jopa yli vuosisadan. 2000-luvun kansankirjoittajien tutkijat ovat kyllä tekstiensä perusteella olleet hyvin tietoisia käsitteiden kuten rah$\operatorname{vas}^{23}$, kansa ja kansanomainen latautuneesta käsitehistoriasta, mutta käsitteitä on käytetty ja sovellettu tästä huolimatta. Kansankirjoittajien tutkimuksen jännitteistä suhdetta tiettyihin käsitteisiin valaisee Anna Kuisminin ja Kirsti Salmi-Niklanderin Kasvatus ja aika -julkaisun teemanumeron Askelia kirjoituksen kentällä (2008) johdantoartikkeliin kirjaamat sanat:

Kansasta ja rahvaasta on puhuttava parempien termien puutteessa: sanoilla tarkoitetaan tässä lähinnä maaseudulla asuneita ei-säätyläisiä, jotka olivat hankkineet oppinsa itse, tavalla tai toisella, tai olivat käyneet koulua vain lyhyen aikaa. Kirjoitustaitoisissa oli talollisia, torppareita, käsityöläisiä, merimiehiä, kirkonvartijoita, lukkareita, renkejä ja ruotuvaivaisia. (Kuismin ja Salmi-Niklander 2008, 2.)

Luettelo kansankirjoittajien ammateista osoittaa, että yhteiskunnallisen ja sosiaalisen asemansa osalta 1800-luvun kansankirjoittajien kirjo oli laaja ja useimmat heistä olivat omassa viiteryhmässään poikkeuksellisia kirjoitustaitonsa vuoksi. Lisäksi eri ryhmien yhteiskunnallisessa asemassa tapahtui 1800-luvun kuluessa merkittäviä muutoksia. Nämä seikat johtavat kansankirjoittajiin ja kansan kokemuksiin kohdistuvan tutkimuksen keskeisiin haasteisiin, jotka kiteytyvät Mikko Lahtisen kirjoittamassaan kirja-arviossa esittämiin kriittisiin kysymyksiin: "Mikä kansa, mikä eliitti?" (Lahtinen 2008, 92; vrt. Stark 2006). Lahtinen peräänkuuluttaa yhteiskunnallisten erojen kehitysvaiheiden systemaattista analysointia ja sitä, että kansankirjoittajien tekstit tulisi kytkeä tiiviimmin rakenteellis-kollektiivisia muutoksia valaisevan tarkastelun yhteyteen (Lahtinen 2008, 93).

Lahtisen kaipaaman kokonaiskuvan muodostaminen vaatisi vielä paljon nykyistä enemmän kansankirjoittajien tekstien systemaattista tutkimusta ja vertailua. Tähän mennessä kansankirjoittajien tutkimuksen painopisteenä on ollut pikemminkin osoittaa, mikä on ollut tiettynä aikana tietyssä asemassa olleille ihmisille mahdollista, ei niinkään sitä, mikä on ollut yleistä tai tyypillistä. Tutkimuskysymykset ovat painottuneet yksilöiden kokemuksiin ja siihen, miten he ovat tulkinneet kulloisiakin yhteiskunnallisia olosuhteita.

Suomessa kansankirjoittajien tutkimus onkin ollut läheisessä yhteydessä tutkimukselliseen lähestymistapaan, jota on kuvattu australialaisen historiantutkijan Martyn Lyonsin käyttöön ottamalla ilmaisulla new history from below. Siinä tarkastelun kohteena ovat nimenomaisesti ruohonjuuritason kirjoitukset ja yksilölliset kokemukset historiallisista muutoksista. Tällaisena se myös eroaa niin kutsutusta old history from below -näkökulmasta, kuten ranskalaisen Annales-koulukunnan ja brittiläisten marxistien tutkimuksista, joissa yhteiskunnan alempia luokkia on tarkasteltu etupäässä kollektiivisena ja anonyymina massana sekä kollektiivisen

muutosprosesseihin ja aatteisiin: modernisaatioon, uskonnollisuuden uusiin muotoihin ja sekularisaatioon, työväenliikkeeseen, nationalismiin ja kansakunnan rakentamisprosesseihin. (Ks. Kuismin ja Salmi-Niklander 2008, 2.) 
aktivismin ja kollektiivisten mentaliteettien näkökulmista. (Lyons 2010; ks. myös Kuismin ja Driscoll 2013, 9; Kauranen 2013, 22-23.)

Kahtiajakautuneista käsitteistä ja niiden käytöstä huolimatta kansan ja eliitin suhde näyttäytyy kansankirjoittajien tutkimuksissa lopulta jatkumona, jossa eri yksilöt sijoittuvat eri kohtiin. Samoin myös itse kirjoitustaito näyttäytyy janana, jonka toisessa päässä on osattu piirtää oma puumerkki ja toisessa päässä on osallistuttu aktiivisesti yhteiskunnalliseen keskusteluun sanomalehtien palstoilla ja kirjoitettu kokonaisia näytelmä- ja romaanikäsikirjoituksia. Näillä janoilla kansa, eliitti ja kirjoitustaito ovat lopulta monella tavalla suhteellisia ja kontekstisidonnaisia käsitteitä. Tämä herättää myös kysymyksen siitä, missä yhteyksissä näiden käsitteiden käytölle on yhä perusteita ja missä yhteyksissä dikotomisten käsitteiden käyttö tavoittaa itse asiassa hyvin huonosti yhteiskunnallisen todellisuuden intersektionaalista luonnetta.

\section{Johtopäätökset}

Kansa-käsitteen historiassa varhaisten runonkerääjien ja -julkaisijoiden, kirjallisuushistorioitsijoiden ja kansanrunoudentutkijoiden ymmärrys ja tavat kuvata suomalaista maalaisrahvasta ovat keskeisessä asemassa hahmotettaessa nykyisen vernakulaari-keskustelun kasvualustaa ja luonnetta. Maaseudulla asuvan väestönosan tuottama perinne, jota haluttiin dokumentoida ja tutkia, määriteltiin pitkään aidoksi sen perusteella, että se oli ei-kirjallista. Ajatus kansasta menneisyyteen palautuvana suullisperäisen runouden välittäjänä oli näkyvissä jo varhaisten kansanrunojulkaisijoiden toiminnassa, mutta erityisesti käsitys vakiintui Lönnrotin Kalevalan myötä ja toistui tutkijoiden kirjoituksissa pitkälle 1900-luvulle saakka. Tutkijoille ja kerääjille todellinen kansa koostui luku- ja kirjoitustaidottomista, ylempien säätyjen ulkopuolisista henkilöistä, joita pidettiin samaan aikaan myös suullisten ja kollektiivisten runojen ja kertomusten aitoina taitajina. Kirjoitettu kerronta, riippumatta kynää käyttävän sosiaalisesta taustasta, rajattiin kansanperinteen tutkimuksen ulkopuolelle. Hieman paradoksaalisesti perinteisen kansankulttuurin dokumentointi ja luokittelu kehitettiin huippuunsa samaan aikaan kun yhteiskunta modernisoitui ja muuttui kiihtyvää tahtia.

Kirjallisuushistoriat hahmottelivat kansalliskirjallisuuden kehityskaarta ja esittelivät niin sivistyneistötaustaisia kirjailijoita ja heidän uusimpia saavutuksiaan kuin myös valikoidusti "talonpoikaisrunoniekkojen" tekstejä ja kansanrunoutta, joka ideaalitapauksessa oli kollektiivista, tekijätöntä. Kirjallisuushistoriallisessa tutkimuksessa käsitteen vernakulaari esiin piirtämä, kansallista kulttuuria varhaisempi paikallisen tekstituotannon kausi auttaa hahmottamaan monisyisemmin sitä prosessia, jolla 1800-luvun kirjallisuushistorioitsijat ja kansanperinteen julkaisijat yhdessä loivat kansakunnalle kronologista syvyyttä. Samanaikaisesti kirjallisuushistoriat rakensivat yhtenäistä, jopa epähistoriallista kuvaa kirjoittavasta kansasta. Niissä Elias Lönnrotin jalostama kansanrunous arvotettiin esteettisin kriteerein korkeammalle kuin muut rahvaan omaehtoiset kirjallisuuden muodot. Tästä huolimatta laulava ja kirjoittava kansa sulautettiin lopulta yhdeksi yhtenäiseksi ilmiöksi. Tilanne muuttui vähitellen, kun käsitys kansanperinteestä, ja laajemmin ajateltuna folkloresta, monimuotoistui.

Suurin uhka niin vanhakantaiselle runoperinteelle kuin itse sivistyneistön 1800-luvulla määrittelemälle homogeeniselle kansa-käsitteelle oli muutos: modernisoituminen, yksilölliset taloudelliset pyyteet, sosiaalinen liikkuvuus ja yhteiskunnallinen aktiivisuus. Tässä ajattelussa myös kansan itsensä tuottamat suulliset ja kirjalliset kertomukset olivat potentiaalisia 
ongelmia. Esimerkiksi rahvaan parissa suosittuja riimillisiä lauluja ja paikallisia runoja ei kelpuutettu kansallisesti kanonisoituihin kansanrunokokoelmiin, Kalevalaan ja Kantelettareen. Samankaltaisen kohtalon kokivat arkkiveisut, jotka pääsivät kirjallisuushistorioihin ainoastaan esimerkkeinä haitallisesta tai epäilyttävästä kirjallisesta toiminnasta.

2000-luvun monitieteisessä kansan kirjallistumisen tutkimuksessa kansanomainen-vernakulaari-käsiteparin esille nousu liittyi osaltaan new history from below -tutkimussuuntaukseen, joka otti tutkimuskohteekseen ruohonjuuritason kirjoitukset ja yksilölliset kokemukset historiallisista muutoksista. 1800-luvun varhaisen keruu- ja julkaisutoiminnan yrityksissä määritellä kansa ja kansanomainen historia hyödynnettiin kansan "omaehtoista" perinnettä valikoiden ja rajaten siinä määrin, että voidaan kysyä, mikä kansanrunokokoelmissa heijastelee kansaa ja kansan suullista perinnettä. Yhteisöjen omaehtoinen kulttuuri-ilmaisu, vernakulaari, alkoikin sisällöllisessä mielessä hahmottua tutkimuksen analyysissa vasta, kun kollektiivinen kansa väistyi ala-ja osakulttuureja sekä yksilöä ja yksilöllisiä tulkintoja korostavien tutkimussuuntauksien tieltä. Vernakulaari voidaankin nähdä yhtenä työkaluna, joka auttaa tutkijaa suuntaamaan katsettaan parin vuosisadan aikana kanonisoituneen kansa-käsityksen katveisiin ja kiinnittämään huomiota siihen, mitä sen heittämiin varjoihin on jäänyt.

\section{Kirjallisuus}

Anttila, Aarne. (1931, 1935) 1985. Elias Lönnrot: Elämä ja toiminta. Helsinki: Suomalaisen Kirjallisuuden Seura.

Anttonen, Pertti. 2005. Tradition Through Modernity: Postmodernism and the Nation-State in Folklore Scholarship. Helsinki: Finnish Literature Society. https://doi.org/10.21435/ sff.15

Apo, Satu. 1998. "Suomalaisuuden stigmatisoinnin traditio."Teoksessa Elävänä Euroopassa: Muuttuva suomalainen identiteetti, toimittaneet Pertti Alasuutari ja Petri Ruuska, 83-128. Tampere: Vastapaino.

Apo, Satu. 2006. "Kansanlaulujen ääni 1700-luvun kirjallisuudessa: Johdatus Macphersonin, Percyn ja Herderin runojulkaisuihin." Teoksessa Herder, Suomi, Eurooppa, toimittaneet Sakari Ollitervo ja Kari Immonen, 216-264. Helsinki: Suomalaisen Kirjallisuuden Seura.

Apo, Satu. 2009. "Uusin Lönnrot-myytti ja kansanrunouden editiohistoria." Elore 16(2). https://doi.org/10.30666/elore.78808

Arwidsson, Aadolf livar. (1821) 1931."Kansallisuudesta ja kansallishengestä [Om Nationalitét och National Anda, Åbo Morgonblad]." Teoksessa Suomen kansalliskirjallisuus VII, toimittaneet Emil Nestor Setälä, Viljo Tarkiainen ja Vihtori Laurila, 103-124. Helsinki: Kustannusosakeyhtiö Otava.

Asplund, Anneli. 2006. "Runolaulusta rekilauluun: Kansanlaulun murros."Teoksessa Suomen musiikin historia. Kansanmusiikki, toimittaneet Anneli Asplund, Petri Hoppu, Heikki Laitinen, Timo Leisiö, Hannu Saha ja Simo Westerholm, 108-165. Helsinki: WSOY.

Bastman, Eeva-Liisa, Kati Kallio ja Tuomas M. S. Lehtonen. 2020. "Vernakulaarin monta tasoa: Näkökulmia Matthias Salamniuksen runoon Ilo-Laulu Jesuxesta." Elore 27(1). https://doi.org/10.30666/elore.89057 
Bauman, Richard. 2008. "The Philology of the Vernacular." Journal of Folklore Research 45 (1): 29-36. https://doi.org/10.2979/JFR.2008.45.1.29

Beecroft, Alexander. 2015. An Ecology of World Literature: From Antiquity to the Present Day. New York: Verso.

Bendix, Regina. 1997. In Search of Authenticity: The Formation of Folklore Studies. Madison: University of Wisconsin Press.

Edlund, Ann-Catrine. 2016. "Preface." Teoksessa Reading and Writing from Below: Exploring the Margins of Modernity, toimittaneet Ann-Catrine Edlund, T. G. Ashplant ja Anna Kuismin, 5-6. Umeå: Umeå University ja Royal Skyttean Society.

Edlund, Ann-Catrine. 2014. "Introduction." Teoksessa Vernacular Literacies: Past, Present and Future, toimittaneet Ann-Catrine Edlund, Lars-Erik Edlund ja Susanne Haugen, 5-11. Umeå: Umeå University ja Royal Skyttean Society.

Evijärvi, Irja-Leena. 1963. Kaarle Krohn: Elämä ja toiminta. Helsinki: Suomalaisen Kirjallisuuden Seura.

Goldstein, Diane. 2015."VernacularTurns:Narrative, Local Knowledge, and Changed Context of Folklore. (American Folklore Society Presidential Address, October 2013)." Journal of American Folklore 128(508): 125-145. https://doi.org/10.5406/jamerfolk.128.508.0125

Gottlund, Carl Axel. 1818, 1821. Pieniä Runoja Suomen Poijille Ratoxi I-II. Uppsala.

Gottlund, Carl Axel. 1828. Väinämöiset, eli meidän nykyisten Runojoin virren-teoista. Tukholma.

Grönstrand, Heidi, Ralf Kauranen, Olli Löytty, Kukku Melkas, Hanna-Leena Nissilä ja Mikko Pollari. 2016. Kansallisen katveesta: Suomen kirjallisuuden ylirajaisuudesta. Helsinki: Suomalaisen Kirjallisuuden Seura.

Haavio, Martti. 1943. Viimeiset runonlaulajat. Helsinki: WSOY.

Hakapää, Jyrki. 2013. Arkkiveisut. Teoksessa Kynällä kyntäjät" Kansan kirjallistuminen 1800-Iuvun Suomessa, toimittaneet Lea Laitinen ja Kati Mikkola, 379-383. Helsinki: Suomalaisen Kirjallisuuden Seura.

Hautala, Jouko. 1954. Suomalainen kansanrunoudentutkimus. Helsinki: Suomalaisen Kirjallisuuden Seura.

Hautala, Jouko. 1957. Johdatus kansanrunoustieteen peruskäsitteisiin. Helsinki: Suomalaisen Kirjallisuuden Seura.

Herder, Johan Gottfried. (1795) 2000. "Lyyra: Lyyrisen runotaiteen luonteesta ja vaikutuksesta" (suom. Vesa Oittinen). Teoksessa Oi runous: Romantiikan ja modernismin runouskäsityksiä, toimittanut Tuula Hökkä, 22-28. Helsinki: Suomalaisen Kirjallisuuden Seura.

Honko, Lauri. 1967. "Perinnelajianalyysin tehtävistä." Sananjalka 9(1): 125-149. https://doi. org/10.30673/sja.86320

Honko, Lauri. 1979. "Perinteen sopeutumisesta." Sananjalka 21(1): 57-76. https://doi. org/10.30673/sja.86430

Howard, Robert Glenn. 2005. "A Theory of Vernacular Rhetoric: The Case of the 'Sinner's Prayer' " Folklore 116(2): 172-188. https://doi.org/10.1080/00155870500140214

Häggman, Kai. 2001. Piispankadulta Bulevardille: Werner Söderström Osakeyhtiö 1878-1939. Helsinki:WSOY. 
Häggman, Kai. 2008. Paras tawara maailmassa: Suomalainen kustannustoiminta 1800-luvulta 2000-luvulle. Helsinki: Otava.

Jalava, Marja. 2014. "Latecomers and Forerunners: Temporality, Historicity, and Modernity in Early Twentieth-Century Finnish Historiography." Teoksessa "Regimes of Historicity" in Southeastern and Northern Europe, 1890-1945: Discourses of Identity and Temporality, toimittaneet Diana Mishkova, Balázs Trencsényi ja Marja Jalava, 43-61. London: Palgrave Macmillan. https://doi.org/10.1057/9781137362476 3

Järvinen, Irma-Riitta ja Seppo Knuuttila (toim.). 1982. Kertomusperinne: Kirjoituksia proosaperinteen lajeista ja tutkimuksesta. Helsinki: Suomalaisen Kirjallisuuden Seura.

Järvinen, Irma-Riitta ja Helena Saarikoski. 1987. Kansanrunoustieteen laitoksen opintotyöt 1886-1985: Luettelo ja asiahakemisto. Helsinki : Yliopistopaino.

Kallio, Kati, Tuomas M. S. Lehtonen, Senni Timonen, Irma-Riitta Järvinen ja Ilkka Leskelä. 2017. Laulut ja kirjoitukset: Suullinen ja kirjallinen kulttuuri uuden ajan alun Suomessa. Helsinki: Suomalaisen Kirjallisuuden Seura.

Karkama, Pertti. 2001. Kansakunnan asialla: Elias Lönnrot ja ajan aatteet. Helsinki: Suomalaisen Kirjallisuuden Seura.

Kaukonen, Väinö. 1979. Lönnrot ja Kalevala. Helsinki: Suomalaisen Kirjallisuuden Seura.

Kauranen, Kaisa. 2013. Mitä ja miksi kansa kirjoitti? Teoksessa Kynällä kyntäjät: Kansan kirjallistuminen 1800-luvun Suomessa, toimittaneet Lea Laitinen ja Kati Mikkola, 19-54. Helsinki: Suomalaisen Kirjallisuuden Seura.

Kauranen, Kaisa ja Mari Myllynen. 2006. Luettelo kansankerääjien käsikirjoituksista ja kirjeenvaihdosta 1831-1910, Suomalaisen Kirjallisuuden Seura, Kansanrunousarkisto. (Painamaton.)

Kauranen, Kaisa. 2005. Luettelo kansankirjoittajista, heidän aineistoistaan ja käymästään kirjeenvaihdosta, Suomalaisen Kirjallisuuden Seura, Kirjallisuusarkisto. (Painamaton.)

Kettunen, Pauli. 2001. "The Nordic Welfare State in Finland." Scandinavian Journal of History, 26(3): 225-247. https://doi.org/10.1080/034687501750303864

Kettunen, Pauli. 2006. "The Tension between the Social and the Economic: A Historical Perspective on a Welfare State. Teoksessa The Road to Prosperity. An Economic History of Finland, toimittaneet Jari Ojala, Jari Eloranta, Jukka Jalava ja Rita Asplund, 285-313. Helsinki: Finnish Literature Society.

Klinge, Matti. 1989. Keisarillinen Aleksanterin yliopisto 1808-1917. Helsinki: Otava.

Knuuttila, Seppo. 1992. Kansanhuumorin mieli: Kaskut maailmankuvan aineksena. Helsinki: Suomalaisen Kirjallisuuden Seura.

Koskimies, Rafael. 1944. Elävä kansalliskirjallisuus I: Suomalaisen hengen vaiheita vv. 18601940. Helsinki: Otava.

Krohn, Kaarle. (1897) 1953. "Esipuhe." Teoksessa Suomalaisen kirjallisuuden vaiheet: Krohn, Julius. 1897 [1953], vii-x. Helsinki: Suomalaisen Kirjallisuuden Seura.

Krohn, Julius. (1897) 1953. Suomalaisen kirjallisuuden vaiheet. Helsinki: Suomalaisen Kirjallisuuden Seura.

Kuismin, Anna ja M. J. Driscoll. 2013. Preface. "Exploring the Processes and Practices of Literacy in the Nordic Countries." Teoksessa White Field, Black Seeds: Nordic Literacy Practices in the Long Nineteenth Century, toimittaneet Anna Kuismin ja M. J. Driscoll, 7-13. Helsinki: Suomalaisen Kirjallisuuden Seura. https://doi.org/10.21435/sflit.7 
Kuismin, Anna ja Kirsti Salmi-Niklander. 2008. "Askelia kirjoituksen kentällä." Kasvatus \& Aika 3(2): 3-5. https://journal.fi/kasvatusjaaika/article/view/68178

Kurkela, Vesa. 1989. Musiikkifolklorismi ja järjestökulttuuri: Kansanmusiikin ideologinen ja taiteellinen hyödyntäminen suomalaisissa musiikki- ja nuorisojärjestöissä. Jyväskylä: Gummerus.

Kuusi, Matti. 1963. Suomen kirjallisuus I: Kirjoittamaton kirjallisuus. Helsinki: Otava.

Lahtinen, Mikko. 2008. "Modernisaation puolesta ja sitä vastaan." Kasvatus \& Aika 3(2): 89-101. https://journal.fi/kasvatusjaaika/article/view/68191

Laitinen, Heikki. 2013. "Kansannuotintajat." Teoksessa Kynällä kyntäjät: Kansan kirjallistuminen 1800-luvun Suomessa, toimittaneet Lea Laitinen ja Kati Mikkola, 379-383. Helsinki: Suomalaisen Kirjallisuuden Seura.

Laitinen, Kai. 1980. "Kirjallisuushistoria: linjanvetoja ja ongelmia." Teoksessa Kirjallisuudentutkijain Seuran vuosikirja 33, 8-50. Helsinki: Suomalaisen Kirjallisuuden Seura.

Laitinen, Lea. 2013. "Rahvaan käsitehistoria." Teoksessa Kynällä kyntäjät: Kansan kirjallistuminen 1800-Iuvun Suomessa, toimittaneet Lea Laitinen ja Kati Mikkola, 55-59. Helsinki: Suomalaisen Kirjallisuuden Seura.

Laitinen, Lea ja Mikkola, Kati. 2013. "Johdanto." Teoksessa Kynällä kyntäjät: Kansan kirjallistuminen 1800-luvun Suomessa, toimittaneet Lea Laitinen ja Kati Mikkola, 9-17. Helsinki: Suomalaisen Kirjallisuuden Seura.

Lantis, Margaret. 1960. "Vernacular Culture." American Anthropologist 62 (2): 202-216. https://doi.org/10.1525/aa.1960.62.2.02a00020

Lassila, Pertti. 1990. Otavan historia. Kolmas osa 1941-1975. Helsinki: Otava.

Launonen, Hannu ja Kirsti Mäkinen (toim.). 1974. Folklore tänään. Helsinki: Suomalaisen Kirjallisuuden Seura.

Leino-Kaukiainen, Pirkko. 2007. "Suomalaisten kirjalliset taidot autonomian kaudella." Historiallinen aikakauskirja 105(4): 429-438.

Liikanen, Ilkka. 2003. "Kansa." Teoksessa Käsitteet liikkeessä: Suomen poliittisen kulttuurin käsitehistoria, toimittaneet Matti Hyvärinen, Jussi Kurunmäki, Kari Palonen, Tuija Pulkkinen ja Henrik Stenius, 257-307. Tampere: Vastapaino.

Linsén, Juhana Gabriel. (1819) 1931. "Suomalaisesta kansallisuudesta [Om Finsk Nationalitet]." Teoksessa Suomen kansalliskirjallisuus VII, toimittaneet Emil Nestor Setälä, Viljo Tarkiainen ja Vihtori Laurila, 258-272. Helsinki: Otava.

Lukin, Karina. 2016. "Murtuvat ja jatkuvat maailmat: Keskusteluja folkloristiikan menneisyydestä ja tulevaisuudesta. Outi Lehtipuron haastattelu." Elore 23(2). https:// doi.org/10.30666/elore.79260

Luukkanen, Tarja-Liisa. 2016. Mitä maalaiskansa luki: Kirjasto, kirjasto ja kirjoja lukeva yhteisö Karstulassa 1861-1918. Helsinki: Suomalaisen Kirjallisuuden Seura.

Lyons, Martin. 2013. "A New History from Below? The Writing Culture of European Peasants c. 1850 - c. 1920."Teoksessa White Field, Black Seeds: Nordic Literacy Practices in the Long Nineteenth Century, toimittaneet Anna Kuismin ja M. J. Driscoll, 146-157. Helsinki: Suomalaisen Kirjallisuuden Seura. 
Lyons, Martyn. 2007. "'Ordinary Writings' or How the 'Illiterate' Speak to Historians." Teoksessa Ordinary Writings, Personal Narratives: Writing Practices in 19th and early 20th-century Europe, toimittanut Martyn Lyons, 13-31. Bern: Peter Lang.

Lönngren, Ann-Sofie, Heidi Grönstrand, Dag Heede ja Anne Heith (eds.). 2015. Rethinking National Literatures and the Literary Canon in Scandinavia. Cambridge: Cambridge Scholars Publishing.

Lönnrot, Elias. 1829. Recension. Helsingfors Tidningar no. 42 https://digi.kansalliskirjasto. fi/sanomalehti/binding/386396?page $=1$ ja 45 . https://digi.kansalliskirjasto.fi/ sanomalehti/binding/386438?page $=1$

Lönnrot, Elias. 1829-1831. Kantele taikka Suomen Kansan sekä Vanhoja että Nykysempiä Runoja ja Lauluja. Osat I-IV. Helsinki: Suomalaisen Kirjallisuuden Seura.

Lång, Reija. 2008. "Mäkitupalaisen tyttärestä kirjailijaksi: Matilda Roslin-Kalliola ja kansallisen kirjoittamisen monet muodot." Kasvatus \& Aika 3(2): 67-80. https://journal. fi/kasvatusjaaika/article/view/68186

Mikkola, Kati. 2009. Tulevaisuutta vastaan: Uutuuksien vastustus, kansantiedon keruu ja kansakunnan rakentaminen. Helsinki: Suomalaisen Kirjallisuuden Seura.

Mikkola, Kati. 2013. "Kansanrunouden kokoelmat. Kerääjinä kuuliaisia avustajia ja visionäärejä." Teoksessa Kynällä kyntäjät: Kansan kirjallistuminen 1800-luvun Suomessa, toimittaneet Lea Laitinen ja Kati Mikkola, 413-463. Helsinki: Suomalaisen Kirjallisuuden Seura.

Niemi, Juhani. 1999. "Melodraamaa ja tosikertomuksia: Suomenkielisen proosan ensi askeleita." Teoksessa Suomen kirjallisuushistoria 1: Hurskaista lauluista ilostelevaan romaaniin, toimittaneet Yrjö Varpio ja Liisi Huhtala, 337-339. Helsinki: Suomalaisen Kirjallisuuden Seura.

Peltonen, Ulla-Maija. 2004. "Kalevalan riemuvuoden kilpakeruu ja hyvän kerääjän käsite." Teoksessa Kansanrunousarkisto, lukijat ja tulkinnat, toimittanut Tuulikki Kurki, 199-217. Helsinki: Suomalaisen Kirjallisuuden Seura.

Polén, Rietrik. (1858) 1988. Johdanto Suomen kirjallishistoriaan: Yliopistollinen kirjoitus. Helsinki: J. C. Frenckell ja poika.

Porthan, Henrik Gabriel. (1766-1778) 1983. Suomalaisesta runoudesta. Kääntänyt ja johdannon kirjoittanut liro Kajanto. Helsinki: Suomalaisen Kirjallisuuden Seura.

Saarelainen, Juhana. 2019. Runous, tieto ja kansa: Elias Lönnrotin ajattelu ja toiminta aikalaisfilosofian kontekstissa. Turku: Turun yliopisto.

Setälä, Emil Nestor, Viljo Tarkiainen ja Vihtori Laurila (toim.). 1933. Suomen kansalliskirjallisuus XII: Talonpoikais- ja taiderunoilijoita, sanomalehti-ja aatteenmiehiä 1800-luvun puoliväliltä. Helsinki: Otava.

Sihvo, Hannes. (1973) 2003. Karjalan kuva: Karelianismin taustaa ja vaiheita autonomian aikana (2. tarkistettu ja täydennetty laitos). Helsinki: Suomalaisen Kirjallisuuden Seura.

Stark, Eija. 2019. "Suullinen kulttuuri ja kirjallinen aineisto: Katsaus folkloristiikan historialliseen itseymmärrykseen." Teoksessa Satuperinteestä nykyrunoon: Suullisen perinteen ja kirjallisuuden yhteyksiä, toimittaneet Niina Hämäläinen, Hanna Karhu ja Silja Vuorikuru, 51-77. Helsinki: Suomalaisen Kirjallisuuden Seura.

Stark, Laura. 2006. "Johdanto: Pitkospuista modernisaation suolle."Teoksessa Modernisaatio ja kansan kokemus Suomessa 1860-1960, toimittaneet Hilkka Helsti, Laura Stark ja Saara Tuomaala, 9-46. Helsinki: Suomalaisen Kirjallisuuden Seura. 
Stenius, Henrik. 2003. "Kansalainen." Teoksessa Käsitteet liikkeessä: Suomen poliittisen kulttuurin käsitehistoria, toimittaneet Matti Hyvärinen, Jussi Kurunmäki, Kari Palonen, Tuija Pulkkinen ja Henrik Stenius, 309-362. Tampere: Vastapaino.

Sulkunen, Irma. 2004. Suomalaisen Kirjallisuuden Seura 1831-1889. Helsinki: Suomalaisen Kirjallisuuden Seura.

Tarkiainen, Viljo. 1934. Suomalainen kirjallisuuden historia. Helsinki: Otava.

Tarkka, Lotte, Haapoja-Mäkelä, Heidi ja Stepanova, Eila. 2019. "Kalevalaisuus, kieliideologiat ja suomalaisuuden myytti." Teoksessa Eurooppa, Suomi, Kalevala: Mikä mahdollisti Kalevalan?, toimittaneet Ulla Piela, Pekka Hakamies ja Pekka Hako, 79-106. Kalevalaseuran vuosikirja 98. Helsinki: Suomalaisen Kirjallisuuden Seura.

Topelius, Zacharias. 1822-1831. Suomen kansan wanhoja runoja ynnä myös nykysempiä lauluja, I-V. Turku: Frenckell ja poika.

VT 2 = Lönnrot, Elias. 1990. Valitut teokset 2: Mehiläinen. Toim. Raija Majamaa. Helsinki: Suomalaisen Kirjallisuuden Seura.

VT 5 = Lönnrot, Elias. 1993. Valitut teokset 5: Muinaisrunoutta. Toim. Raija Majamaa. Helsinki: Suomalaisen Kirjallisuuden Seura.

Filosofian tohtori Niina Hämäläinen on väitellyt folkloristiikasta Turun yliopistossa. Hän työskentelee Kalevalaseuran toiminnanjohtajana. Parhaillaan hänellä on työn alla Kalevalan kriittinen editio, Avoin Kalevala, sekä Suomen Akatemian projektissa (nro 322071) väheksyttyjen aineistojen tutkiminen.

Filosofian tohtori Kati Mikkola on väitellyt uskontotieteestä Turun yliopistossa. Hän on Helsingin yliopiston folkloristiikan dosentti ja työskentelee opetusneuvoksena Opetushallituksessa.

Filosofian tohtori llona Pikkanen on väitellyt historiantutkimuksesta Tampereen yliopistossa. Hän toimii Suomalaisen Kirjallisuuden Seuran tutkimusosaston tutkimuspäällikkönä ja tutkii historiankirjoituksen historiaa ja historiakulttuuria.

Filosofian tohtori Eija Stark on väitellyt folkloristiikasta Helsingin yliopistossa. Hän on tutkijana Suomalaisen Kirjallisuuden Seurassa ja tutkii Åbo Akademiin sijoittuvassa Suomen Akatemian projektissa (nro 308534) modernisaation ja kaupallisuuden vaikutuksia kansankulttuuriin ja kertomusperinteeseen. 